\title{
trabalhonecessário
}

issn: $1808-799 \mathrm{X}$

ano 6 - número 6 - 2008

\section{CONCEPÇÃO DE EDUCAÇÃO TECNOLÓGICA NA REFORMA DO ENSINO MÉDIO E TÉCNICO NO GOVERNO FHC: resultado de um processo histórico*}

Zuleide Simas da Silveira** zuleidesilveira@terra.com.br

\section{Resumo:}

O presente trabalho tem o objetivo de desvelar os desdobramentos da concepção de educação tecnológica no Brasil, desde sua gênese nos anos de 1960 até os documentos legais produzidos no final dos anos de 1990. A pesquisa orientou-se pelas seguintes questões: qual o conceito de educação tecnológica? Por que o termo passa a ser exaltado, deixando cair no esquecimento nomenclaturas como, educação técnica, formação técnicoprofissional e ensino profissional? Qual a concepção de educação tecnológica que norteou as políticas educacionais dos anos de 1990? Na tentativa de cumprir com o desafio de responder a essas questões, faço uma recuperação dos fatos históricos que marcaram a evolução não apenas dos termos que denotam a formação para o trabalho, mas, também, da concepção de educação que está por detrás desses modos de expressão. Para alcançar os objetivos da pesquisa foi realizada revisão de literatura em economia política: Estado brasileiro e suas relações com o imperialismo; Estado brasileiro, classes sociais e formação da força de trabalho; educação média e técnica no Brasil e reformas educativas, como também levantamento de fontes primárias: documentos emanados do Poder Executivo e Legislativo; de entidades de classe como, o patronato, CUT e ANDES; do poder docente Conselho de Dirigentes dos Centros Federais de Educação Tecnológica (CONCEFET); Associação Nacional dos Dirigentes das Instituições de Ensino Superior (ANDIFES); Conselho Diretor (CODIR) e Conselho de Professores (CONSEP). Para chegar ao concreto real, síntese de múltiplas determinações, a escolha do caminho para abordagem do tema foi o método do materialismo histórico, método de análise da realidade e produção do conhecimento, por meio da crítica à economia política, o que exige um movimento dialético, de modo a captar as contradições do desenvolvimento histórico do processo de formulação das políticas de ensino médio e técnico no país e suas mediações nas relações entre capital e trabalho, trabalho e educação, ou, em outras palavras, o referido método permitiu 
compreender como e porque se articulam as políticas de formação da força de trabalho no processo de desenvolvimento econômico e social, na realidade concreta da sociedade brasileira.

Palavras-chave - Política educacional; educação; concepção de educação tecnológica

\section{Introdução}

As reformas da educação empreendidas ao longo do século $X X$, tendo continuidade nesse início de século, admitiram pequenos ajustes de modo a corrigir 'distorções' que, porventura, não estivessem indo ao encontro das determinações estruturais da sociedade capitalista, aproximando, cada vez mais, a escola do trabalho, aos interesses do mercado, por meio de sucessivas reformas. É nesse contexto que analiso como foi se formando o consenso sobre a concepção de educação tecnológica que norteou a reforma do ensino médio e técnico promovida no final da década de 1990.

Os anos de 1990 têm um significado para além da ruptura com o padrão de acumulação promovido pelo Estado nacional-desenvolvimentista. $\mathrm{Na}$ realidade concreta, representam, também, uma inversão na cultura empresarial e nos princípios políticos no que concerne ao debate ocorrido entre defensores do livre mercado, representados por Eugênio Gudin, e aqueles que advogavam que o país só alcançaria a industrialização por meio de um Estado forte e provedor da industrialização que adotasse a política de substituição de importação e de reserva de mercado, liderados por Roberto Simonsen, nos anos de 1940.

A década de 1990 foi o marco do retorno desse debate, trazendo o ressurgimento das idéias de Gudin (Setúbal, 2005, p.421), quando se promoveu a abertura comercial ao capital imperialista, com base no acirramento da competitividade na economia e das privatizações que caracterizaram o processo de desnacionalização, sob a justificativa governamental de conquistar investimentos em infra-estrutura; e quando, ainda, foram criadas agências reguladoras com a finalidade de se oferecer caráter de gestão estatal da economia, com base na concorrência. Portanto, trata-se de uma velha ideologia que desempenha uma 
função política nova e, em parte, paradoxal: a de exaltar o mercado em benefício dos monopólios e contra os direitos sociais (Boito, Jr., 1996).

Conseqüentemente, os governos de Collor de Mello e Fernando Henrique Cardoso, apesar de terem chegado ao poder pelo voto popular, expressam a constituição de uma hegemonia burguesa de concepções e propostas políticas neoliberais. Iniciada no governo Collor, e aprofundada no período FHC, a subordinação do Brasil à nova (des)ordem do capital mundial ocorreu sob o discurso de modernização produtiva e inserção competitiva, promovendo, assim, a (re)inserção do país na nova divisão internacional do trabalho, marcada pelo aumento da produtividade e da superexploção do trabalho.

Entre 1990 e 1991, foram implantados vários programas com a participação efetiva da burguesia industrial, a exemplo do Programa Brasileiro de Qualidade e Produtividade (PBQP), Programa de Apoio à Capacitação Tecnológica da Indústria Brasileira (PACTI), Programa de Competitividade Industrial, Projeto de Reconstrução Nacional e o Programa Setorial de Educação. No que se relaciona à participação do empresariado industrial na política educacional brasileira, Rodrigues (1998) destaca a presença desse patronato, por meio da Confederação Nacional da Indústria (CNI), no campo de luta hegemônica pela definição dos fins, objetivos, métodos e estrutura da educação. Também os organismos multilaterais, como o Fundo Monetário Internacional (FMI), Banco Mundial (BIRD), Banco Interamericano de Desenvolvimento (BID) e o Programa das Nações Unidas para o Desenvolvimento (PNUD), passam a ter o papel de tutoriar reformas dos Estados nacionais, principalmente dos países de capitalismo dependente. No plano jurídico-econômico, a Organização Mundial do Comércio (OMC) vai tecendo uma legislação cujo poder transcende o domínio das megacorporações e empresas transnacionais. Ressaltese que, em 2000, a OMC sinalizou para o capital que o campo da educação é um dos espaços mais fecundos para negócios rentáveis (Frigotto; Ciavatta, 2003). Nesse caso, as Organizações das Nações Unidas para a Educação, a Ciência e a Cultura (UNESCO) entram em cena como órgão de assessoria técnica na organização pedagógica, realizando grandes eventos de farta produção documental.

Ainda nos anos de 1990, em nível regional, outros organismos servem de sustentáculos aos primeiros. No caso da América Latina, destaca-se, no plano econômico, a Comissão Econômica para a América Latina e Caribe (CEPAL), no plano educacional, a Oficina Regional para a Educação na América Latina e no 
Caribe (OREALC) e, no plano mais abrangente, o Acordo de Livre Comércio das Américas (ALCA).

A CEPAL dos anos 1990 incorporou o debate internacional sobre a necessidade de se reformularem os sistemas educacionais de modo a ajustá-los às mudanças no setor produtivo e das transformações decorrentes de uma competição em nível global, formulando, em 1992, o documento Educación y conocimiento: eje de la transformación productiva con equidad. O objetivo era o de assegurar o progresso técnico para a América Latina e Caribe, garantindo que a reestruturação econômica fosse acompanhada de eqüidade social, o que foi preconizado na publicação Transformación productiva con equidad. Desse modo, do ponto de vista dos cepalinos a educação é o principal instrumento na construção de uma nova realidade econômica e social para os países em desenvolvimento, estratégia central da competitividade, em um contexto de globalização marcada pela sociedade do conhecimento.

Vasta documentação emanada de importantes organismos multilaterais propalou esse ideário a partir de diagnósticos, análises e propostas de soluções consideradas fundamentais a todos os países da América Latina e Caribe, tanto no que se refere à educação, quanto à economia. As bases para o projeto de educação em nível mundial foram determinadas na Conferência Mundial sobre Educação para Todos ${ }^{1}$ realizada em Jomtien, Tailândia, de 5 a 9 março de 1990, cuja meta 'viável' é a Satisfação das Necessidades Básicas de Aprendizagem (NEBAS), as quais compreendem tanto os instrumentos essenciais para a aprendizagem (como leitura e escrita, expressão oral, cálculo, solução de problemas), quanto os conteúdos básicos da aprendizagem (conhecimentos, habilidades, valores e atitudes), necessários para que os seres humanos possam sobreviver, desenvolver plenamente suas potencialidades, viver e trabalhar com dignidade, participar plenamente do desenvolvimento, melhorar a qualidade de vida, tomar decisões fundamentadas e continuar aprendendo (UNESCO, 1990).

É acenando com tais conhecimentos teóricos e práticos, capacidades, valores e atitudes que a UNESCO pretende em 'Educação para Todos' (con)formar crianças, jovens e trabalhadores, "entendendo que a educação pode contribuir para conquistar um mundo mais seguro, mais sadio, mais próspero e ambientalmente mais puro, 
que, ao mesmo tempo, favoreça o progresso social, econômico e cultural, a tolerância e a cooperação internacional" (UNESCO, 1990)².

A função ideológica do conceito de Satisfação das Necessidades Básicas de Aprendizagem, lançado pela Conferência de Jomtien, encontra boa acolhida por parte dos denominados 'arautos da reforma'3, elaboradores do Plano Decenal da Educação para Todos (1993-2003), no governo Itamar Franco, sucessor de Collor de Mello. Simultaneamente à derrocada de Collor de Mello, Itamar Franco abre espaço para que o então candidato à Presidência da República, Fernando Henrique Cardoso, construa a hegemonia e chegue ao poder, derrotando o candidato do Partido dos Trabalhadores, Luiz Inácio Lula da Silva. Nesse cenário, a correlação de forças no Congresso Nacional é alterada, modificando-se o rumo do projeto de LDB delineado pelo movimento popular no final da década anterior.

Posteriormente, no ano de 2000, foi realizado O Marco de Ação de Dakar, em Dakar, Senegal, no período de 26 a 28 de abril, no qual os participantes da Cúpula Mundial de Educação comprometeram-se a alcançar os objetivos e metas ${ }^{4}$ de Educação para Todos.

A partir das Recomendações e Acordos que os Estados-Nações de capitalismo dependente estabelecem com as organizações multilaterais, a educação passa à política prioritária do Banco Mundial, tornando-se, então, 'núcleo sólido' para ‘aliviar' a pobreza e promover a ideologia da globalização.

O mais importante a destacar é o pressuposto axial de que a educação é uma condição necessária para a reprodução econômica e ideológica do capital. A educação (e mais especificamente, a formação profissional a ela associada) tem como uma de suas principais funções transformar imaginariamente a divisão social do trabalho em resultado escolar, despolitizando, por meio de noções de dom, aptidão e mérito, as contradições fundamentais do capitalismo (Leher, 1998, p.86).

É nesse contexto que o governo Fernando Henrique Cardoso, tendo como objetivo abrir novas áreas de acumulação para o capital privado, a exemplo da educação, aprova vários instrumentos legais que regem, até os dias de hoje, a estrutura e organização do sistema educacional brasileiro. Em seus dois mandatos (1995-2002), FHC contou apenas com um ministro, Paulo Renato de Souza, economista, ex-secretário de educação do estado de São Paulo, ex-reitor da Universidade Estadual de Campinas, com passagem pelo BID. A proposta de 
governo para o primeiro mandato foi elaborada por uma equipe coordenada pelo economista Paulo Renato Souza, cujo destaque foi o papel econômico da educação atrelado ao novo modelo de desenvolvimento. Ressalte-se que a base de sustentação e dinâmica do novo desenvolvimento econômico é externo, fundamentada na importação de ciência e tecnologia.

Essa indução atuaria no sistema educacional pelo topo, isso é, pela
universidade, entendendo-se que a competência científica e
tecnológica é fundamental para garantir a qualidade do ensino
básico, secundário e técnico, assim como aumentar a qualificação
geral da população. Para se conseguir isso, a proposta afirmava a
necessidade de se estabelecer uma 'verdadeira parceria' entre setor
privado e governo, entre universidade e indústria, tanto na gestão
quanto no financiamento do sistema brasileiro de desenvolvimento
científico e tecnológico (Cunha, 2003) ${ }^{5}$.

Com base no tripé da plataforma de política neoliberal - constituído pelo aprofundamento da abertura comercial, pela privatização de empresas e de serviços públicos, e, ainda, pela desregulamentação das relações de trabalho - além da apropriação dos novos paradigmas tecnológicos, o capital mediado pelo governo Cardoso colocou a necessidade de serem efetivadas alterações significativas na educação, envolvendo as políticas públicas educacionais, o funcionamento dos sistemas de ensino, suas concepções, o currículo dos cursos, etc.; enquanto o trabalho respondia, predominantemente, às pressões das transformações econômicas e tecnológicas com elevação e persistência das taxas de desemprego, proliferação de oportunidades ocupacionais com condições de trabalho de pior qualidade, cristalização dos baixos rendimentos das massas.

A ideologia salvacionista de governos anteriores é renovada pelo Estado neoliberal que vem atribuindo à educação 0 poder de sustentação da competitividade. Em outras palavras: mais uma vez na história do sistema educacional brasileiro, se atribui à educação, êxitos e, ou, atrasos no campo econômico, político e social. Neste sentido, o governo Cardoso promoveu a reforma da educação brasileira por meio da Lei de Diretrizes e Bases da Educação Nacional, n 9.394/96, promulgada em consonância com a ideologia neoliberal de valorização dos mecanismos de mercado, descentralização, privatização, desregulamentação das leis trabalhistas, "é uma 'LDB minimalista', compatível com o Estado mínimo" (Saviani, 2003, p. 200). 
Certamente essa via foi escolhida para afastar as pressões das forças organizadas que atuavam junto ou sobre o Parlamento de modo a deixar o caminho livre para a apresentação e aprovação de reformas pontuais, tópicas, localizadas, traduzidas em medidas como o denominado 'Fundo de Valorização do Magistério', os 'Parâmetros Curriculares Nacionais', a lei de reforma do ensino profissional e técnico, a emenda constitucional relativa à autonomia universitária, além de outras como os mecanismos de avaliação mediante provas aplicadas aos alunos do ensino fundamental e médio e o 'provão'6 para os universitários (Saviani, 2003, p. 200).

Com a promulgação da LDB minimalista em dezembro de 1996, o governo Cardoso efetiva uma nova institucionalidade no campo educacional. FHC e o ministro da educação usaram de sua legitimidade, competência e base política para pôr em prática, pelo alto, seu projeto societário, regulamentando a nova lei, via leis complementares, decretos, portarias ministeriais, pareceres, resoluções e medidas provisórias. Assim sendo, o Decreto n 2.208/97, que acompanhado da Portaria no 646/97 e da Portaria do MEC nº 1005/97, promoveu a reforma do ensino médio e técnico no Brasil.

É, pois, da concepção de educação tecnológica que norteou esta reforma que trato a seguir.

\section{A gênese da concepção de educação tecnológica no Brasil}

\section{Contexto socioeconômico e político}

O caráter do Estado Nacional ${ }^{7}$-Desenvolvimentista ${ }^{8}$ é o de organizar a sociedade "pelo alto", tanto forjando o processo de industrialização, quanto promovendo mudanças sociais que acompanham a constituição do capitalismo. A Revolução de 1930, resultado do embate entre aqueles que se identificavam com a modernidade (vencedores) e aqueles que se identificavam com o progresso (liberais da velha ordem agrário-exportadora), foi a de uma hegemonia em torno da qual era preciso construir uma ordem que partisse "de cima", portanto de um Estado forte e centralizador. Não resta dúvida que, tanto para vencedores quanto para liberais, essa ordem deveria ser construída a partir do papel que o Estado deveria assumir, cabendo ao aparelho estatal criar instituições e mecanismos em geral para o funcionamento da ordem burguesa.

Nesse cenário, o nacionalismo no Brasil nasce em seu caráter como contraditório. Se, por um lado, o nacionalismo só pode existir a partir da formação do 
Estado-Nação, no qual sua força política remonta à Revolução Burguesa, defensora de uma comunidade política igualitária, universalizante, no qual liberdade, igualdade se encontram com democracia; de outro, após a consolidação dos estados nacionais, surgem disputas entre eles que, entrelaçadas com os processos de reorganização geopolítica mundial e de formação do capital monopolista, fazem com que o apelo à idéia de nação passe a significar a submissão aos desígnios do Estado, dissociando-a do princípio democrático. No Brasil, em particular, o nacionalismo será confundido com um estatismo autoritário e excludente, relegando a classe trabalhadora não só à exploração, como, também, ao absenteísmo político.

O Brasil é o país que melhor representa esse modelo histórico de revolução autocrático-burguesa. Nele a militarização do poder estatal serviu de fulcro à reaglutinação e à reorientação da dominação burguesa, adaptando-se às complexas e drásticas exigências de uma rápida transição para o capitalismo monopolista, sob impulsão e controle econômicos externos. O crescimento capitalista foi acelerado até o ponto do 'milagre econômico', enquanto a estabilidade política foi lograda em limites de 'quase' 'estagnação' (Fernandes, 1995, p.134).

No plano político, o pressuposto é que somente um Estado forte e intervencionista estaria apto a assumir as tarefas que se impunham para a industrialização; afirmando que o Estado liberal seria incapaz de enfrentar com competência os novos problemas com que se deparava o país, os vencedores defendiam o papel regulamentador e disciplinador do Estado em relação aos mecanismos de mercado, além de sua intervenção como provedor da industrialização criando empresas estatais. O antiliberalismo dos autoritários, no entanto, não os impedia de preservar a iniciativa privada e de buscar a consolidação do capital.

No período de 1945-1964, não há clima para defesa de projetos autoritários. O tom do discurso nacionalista nesse período do tempo histórico é dado pela esquerda9. Há uma certa continuidade institucional entre o período do Estado Novo e o período democrático, combinando-se instituições corporativo-estatais e liberaldemocráticas, estando o poder de decisão centralizado nas mãos da burocracia estatal e exercido com grande autonomia em relação aos partidos políticos.

Nesse período democrático, o nacionalismo é caracterizado pelo forte apelo terceiro-mundista, tendo à frente organizações que se reivindicavam de esquerda, a 
exemplo do Instituto Superior de Estudos Brasileiros (ISEB), Clube Militar, Frente Parlamentar Nacionalista, Partido Comunista Brasileiro (PCB) ${ }^{10}$, etc., seguramente influenciadas pelos movimentos de descolonização na África e Ásia e pelos regimes nacionalistas de Nasser no Egito, Sukarno na Indonésia e Nerhu na Índia, que questionavam o domínio das superpotências.

Os princípios democráticos, nos anos de 1950, serão deslocados das questões centrais do nacionalismo de esquerda. Eles ressurgirão na esquerda dos anos que sucedem as mazelas deixadas pelo regime militar.

Entrementes, nos anos de 1950, a reflexão política stricto sensu é ainda muito precária, havendo predominância de temas econômicos nos debates políticos, deixando implícita a idéia de que o desenvolvimento político e social era engendrado pelo desenvolvimento econômico. Nesse sentido, o nacionalismo é de cunho econômico, cujas motivações prendem-se mais às razões do Estado do que a quaisquer motivações de inspiração jacobina. Seu objetivo é a construção de uma economia forte, em defesa do Estado brasileiro. Por isso, então, afirmo que o nacionalismo é muito mais um "estatismo", promovendo o desenvolvimento das forças produtivas capitalistas.

No tocante aos aspectos econômicos, é possível afirmar que, desde seu início, o processo de desenvolvimento industrial no Brasil, em fins do século XIX e início do século XX, ocorre de forma crescente, marcado por contradições internas e externas, no sentido de se constituir dentro do sistema capitalista mundial. $O$ processo de implantação da indústria no Brasil - o industrialismo - foi marcado pela expansão de algumas unidades que usam, predominantemente, tecnologia importada e força de trabalho imigrante, período em que o modelo de acumulação baseava-se na "natural vocação agrícola" do país. Diferentemente do processo de industrialização que engendra modificações estruturais na sociedade, sendo o setor da indústria o que mais cresce no conjunto da economia, o industrialismo, no entanto, não é a estrutura econômica da sociedade (Brandão, 2006; Miceli, 1992 apud Cunha, 2000).

Desde o início da Primeira República, destacam-se dois pensamentos distintos sobre os rumos do processo de industrialização. De um lado, o pensamento liberal econômico combatia toda e qualquer espécie de auxílio do Estado em favor da indústria, sustentando que as indústrias naturais ${ }^{11}$ seriam capazes de se 
desenvolver, por si sós, desde que contassem com mão-de-obra adequada e facilidade nos meios de transporte. De outro, os protecionistas pleiteavam a proteção sistemática, quase que planificada, preferencialmente, para as indústrias naturais.

Esse confronto irá se estender até a metade dos anos de 1940, quando os protecionistas, agora denominados de desenvolvimentistas, serão liderados uns por Eugênio Gudin e, outros, por Roberto Simonsen. Os primeiros partiam do pressuposto de que o país era portador de vocação agrícola, precisando, apenas, de incentivo às atividades agrícolas para se desenvolver. Defendiam a entrada não só de capital estrangeiro, mas também de tecnologia avançada. No caso do petróleo, em particular, os gudinianos, por serem contrários, por princípios, à intervenção do Estado na economia, propunham que a exploração do mineral fosse entregue às companhias estrangeiras.

Para os desenvolvimentistas liderados por Simonsen, a intervenção do Estado na economia era primordial para promover o desenvolvimento, o que permitiria o aumento da produção de bens de consumo; expansão do mercado interno e elevação da renda nacional. Além do que, para Simonsen, o Brasil precisaria superar o subdesenvolvimento afim de atingir o estágio de desenvolvimento dos Estados Unidos e da Europa. Para tal, seria necessária a entrada de capital estrangeiro e tecnologia, sem, no entanto, concorrer com as empresas nacionais, ou melhor dizendo, os investimentos poderiam ser realizados de forma associada aos grupos nacionais.

Um terceiro grupo de desenvolvimentistas via na ampliação da intervenção do capital externo e na entrada de tecnologia, manifestações do imperialismo; grosso modo, o debate, em geral, era favorável à vinda de capital estrangeiro, desde que submetido ao controle do governo brasileiro que subordinaria o fluxo de capitais aos interesses da nação ${ }^{12}$.

Depois de ter experimentado a fase em que a II Guerra Mundial propiciou à América Latina exportar novos produtos além dos tradicionais, o repúdio dos desenvolvimentistas ao capital estrangeiro era sufocado pela defesa da industrialização. Entretanto, finda a guerra, o comércio internacional se reorganizou, levando os países de capitalismo central a exigir que os países periféricos voltassem a exportar apenas seus antigos produtos. 
Nesse contexto, surge a $\mathrm{CEPAL}^{13}$ com o objetivo de realizar estudos sobre a América Latina, bem como justificar o atraso em relação aos denominados países desenvolvidos e buscar meios de superá-lo. Do ponto de vista dos cepalinos a saída estava na adoção de políticas por parte de um Estado centralizador e intervencionista na economia, voltadas para o desenvolvimento da indústria de base e de bens de consumo direcionados ao mercado interno.

A despeito de ser um nacionalista, exemplo de presidente nacionaldesenvolvimentista, Vargas não se viu impedido de fazer constantes apelos ao capital estrangeiro. É inegável que adotou medidas de cunho nacionalista; uma das políticas mais relevantes para o processo de industrialização é a participação do Estado na criação da indústria de base, que tinha por objetivo retirar o país de sua dependência frente à importação de insumos e matérias-primas básicas. Para tal, o governo beneficia o empresariado barateando o custo da produção e criando estatais, a exemplo da Companhia Siderúrgica Nacional (CSN), em 1941; da Companhia Vale do Rio Doce, em 1942; da Fábrica Nacional de Motores (FNM) e da Fábrica Nacional Álcalis, em 1943.

Além disso, o governo Vargas interveio de forma abrangente nas questões sociais, cujo marco é a Consolidação das Leis do Trabalho (CLT), em 1943, com a finalidade de disciplinar as relações entre capital e trabalho; afinal, um novo modo de acumulação vinha se instalando no país, sendo necessária a formação do "exército de reserva" adequado à reprodução do capital (Oliveira, 2003). Vargas criou, ainda, o Partido Trabalhista Brasileiro (PTB) para dar expressão política ao sindicalismo oficial e corporativo, que tinha como base a integração dessas entidades e de suas lideranças ao Estado.

Em 1952, em seu segundo governo, optou por uma política nacionalprogressista, criando o Banco Nacional de Desenvolvimento Econômico (BNDE ${ }^{14}$ ), o Plano Nacional de Estradas e o Fundo Nacional de Eletrificação, o monopólio estatal do petróleo (Petrobras) e o projeto de monopólio estatal de energia elétrica (Eletrobrás). Além disso, ainda enviou ao Congresso um projeto de lei limitando os lucros extraordinários e restringindo a exportação de lucros. Tais medidas foram acompanhadas de uma política destinada a atrair o apoio da classe trabalhadora, mediado pelo então Ministro do Trabalho, João Goulart. 
Entretanto, para Vargas, a entrada de capitais estrangeiros tinha o significado de unir forças políticas em torno do desenvolvimento identificado com o processo de industrialização, chegando até a afirmar que se trataria de uma relação imperialista, apenas, se a política adotada pelo governo americano mantivesse o Brasil sem recursos e, portanto, sem desenvolvimento.

Tratando-se de projeto de industrialização e de desenvolvimento econômico em bases capitalistas, não havia qualquer razão que forçasse qualquer rompimento definitivo com o chamado 'bloco ocidental'. A própria ideologia 'nacional-desenvolvimentista', aliás, apontava para a convergência entre os interesses nacionais e os do referido bloco, clamando por intervenções externas capazes de empolgar o processo de desenvolvimento e amenizar as desigualdades sociais. Em todas as mensagens ao Congresso Nacional, Vargas ponderou a necessidade de atrair capital estrangeiro, de 1951 a $1954^{15}$.

É, pois, no segundo governo Vargas que são lançadas as base instrumentais da política econômica da década. Promove-se a reforma cambial, faz-se concessão de subsídios para aplicação de bens de capital e insumos necessários ao desenvolvimento industrial e viabiliza-se, por meio da operação de compra e venda de divisas, a participação financeira do Estado nas rendas de intercâmbio.

A passagem do nacional-desenvolvimentismo, dependente de insumos e matérias-primas básicas, para o nacional-desenvolvimentismo, que aceitava a associação crescente com monopólios internacionais, ocorre a partir da Instrução no $113^{16}$ da Superintendência da Moeda e do Crédito (SUMOC), de 1955, já no governo interino de Café filho, responsável pelo processo de aceleração e consolidação da industrialização. A partir de então, os setores da burguesia brasileira que se beneficiam da associação ao capital internacional passam a adotar como genuína a relação entre capital brasileiro e capital internacional.

Todavia, essa medida liberalizante em relação ao capital internacional não influenciou o discurso nacionalista, nem a atuação do Estado. Já no governo Juscelino Kubitschek (1956-1961), é lançado o ambicioso programa de desenvolvimento econômico, o Plano de Metas, cujo slogan era desenvolver 50 anos em 5. O Plano se apoiava na Instrução no 113, buscando o crescimento econômico do país associado ao capital estrangeiro, em detrimento de uma política 
de estabilidade monetária, possibilitando a entrada de empresas estrangeiras, principalmente, no setor automotivo.

Nesse cenário, a indústria de base no Brasil é um dos setores que mais recursos recebeu ao lado dos ramos de energia e de transportes. No entanto, outras áreas igualmente incluídas no plano desenvolvimentista, como alimentação e educação, não mereceram o mesmo tratamento por parte do Estado. Vale destacar que o governo $\mathrm{JK}$ acaba por estabelecer o tripé que marcaria o modelo da industrialização brasileira até bem recentemente: o Estado atuando como agente fomentador, investindo em infra-estrutura, captando recursos financeiros e agindo em segmentos da indústria de base; a indústria nacional atuando na produção de bens de consumo e fornecendo serviços às multinacionais; e, as multinacionais atuando na produção de bens de consumo duráveis (CPDOC) ${ }^{17}$.

Entrementes, a expansão econômica foi notável. O total de investimentos e financiamentos de origem externa chega, em menos de cinco anos, a quase 2 bilhões e 500 milhões de dólares, destinados quase na sua totalidade à indústria manufatureira e de base; na compra de máquinas e equipamentos já obsoletos nos Estados Unidos, indicando a posição do capital internacional na economia brasileira (Marini, 2000, p.87).

Aceitando essa associação e benefícios das fontes de crédito e de novas tecnologias, as grandes empresas nacionais aumentavam, cada vez mais, não só a extração de mais-valia, mas, também, seu poder de competição no mercado interno. Esse processo teria sido responsável pela quebra de pequenas empresas, ao mesmo tempo em que permitiria a concentração de capital na formação de monopólios.

Do modelo nacional-desenvolvimentista de Vargas ao modelo nacional-desenvolvimentista de JK há continuidade e ruptura. Em 1959, quando JK, buscando desvincular o Plano de Metas do Programa de Estabilização Monetária, rompe com o $\mathrm{FMI}^{18}$, entretanto, novos acordos com o organismo serão retomados em 1961, 1965 e 1972.

Empossado em 1961, João Goulart colocou em prática uma política nacionalista, realizando um governo contraditório: por um lado, procurou estreitar alianças com o movimento sindical e setores nacional-reformistas; de outro, 
implementou uma política de estabilização baseada na contenção salarial. Seu Plano Trienal de Desenvolvimento Econômico e Social, elaborado pelo ministro do Planejamento Celso Furtado, tinha por objetivo manter as taxas de crescimento da economia e reduzir a inflação. Essas condições, exigidas pelo FMI, seriam indispensáveis para a obtenção de novos empréstimos, para a renegociação da dívida externa e para a elevação do nível de investimento.

O Plano trienal trazia em seu bojo a realização das denominadas reformas de base: agrária, fiscal, educacional, bancária e eleitoral, o que acirrou o embate entre forças conservadoras e progressistas, elevando o índice de oposição ao governo. Embora o Plano Trienal tenha sido abandonado em meados de 1963, o Presidente continuou a implementar medidas de caráter nacionalista, quais sejam, limitar a remessa de capital para o exterior, nacionalizar empresas de comunicação e inspecionar as concessões para exploração de minérios. Em decorrência, a retaliação política, por parte do governo estadunidense e empresas privadas norteamericanas concretizaram-se no corte de crédito ao Brasil, interrompendo, desse modo, a negociação da dívida externa.

No cenário de crise econômica e política, no dia 13 de março de 1964, em razão da realização de um grande comício em frente à Estação Central do Brasil, no Rio de Janeiro, João Goulart decretou a nacionalização das refinarias privadas de petróleo e desapropriou, para a reforma agrária, propriedades às margens de ferrovias, rodovias e zonas de irrigação de açudes públicos.

É neste cenário que os militares tomam o poder, em $1^{\circ}$ e abril de 1964 , dando prosseguimento ao modelo adotado por Vargas para a industrialização. Com a finalidade de tornar o Brasil uma grande potência bélica e econômica, os militares concebiam um Estado forte, centralizador e intervencionista, que substituísse a política pela técnica, e capaz de zelar pela segurança nacional.

Marini (2000) caracteriza o governo de Castelo Branco pela atuação internacional distinta da chamada 'política externa independente', praticadas nos governos de Jânio Quadros e de João Goulart, e que se baseava nos princípios de autodeterminação e de não intervenção. Ressalta que Vasco Leitão da Cunha assumiu a direção do Ministério de Relações Exteriores, em 1964, refutando a idéia de uma política externa independente e invocando razões geopolíticas, que vinculariam estreitamente o Brasil ao mundo ocidental e, particularmente, aos 
Estados Unidos. Com esse argumento, as relações internacionais vinculam-se a política de interdependência continental (p.58-9).

Os militares no poder mantiveram a busca no exterior dos recursos necessários para alcançar o desenvolvimento do Brasil, a partir da expansão dos mercados externos, da introdução de um moderno capitalismo no Brasil de tipo associado, ou, melhor dizendo, capitalismo dependente. O desenvolvimento, em seu aspecto político, esteve vinculado, primordialmente, aos interesses das frações internacionalizadas da burguesia associada aos capitais internacionais oligopolizados.

Entre 1964 e 1973, com a política de crescimento focalizada na economia, não foi apenas a indústria que avançou, mas, também, a agricultura e o setor de serviços. Nesse período, o investimento na industrialização substitutiva de importações foi essencialmente do Estado. O milagre econômico iniciado em 1967 atinge seu ápice em 1970-73, quando é interrompido pela crise mundial do capital, em particular a do petróleo, em 1973, que, internamente, engendrou contradições do capital. Nesse cenário, o Brasil se viu diante de duas alternativas: a primeira, seria evitar o endividamento e a inflação; a outra, seria de buscar dar continuidade ao projeto de desenvolvimento. Nesse contexto, é sancionado o segundo Plano Nacional de Desenvolvimento (II PND).

Elaborado para o período 1974-1979, o II PND propunha uma mudança na estrutura da economia que pudesse aumentar a competitividade internacional da economia brasileira, reduzindo as importações e aumentando as exportações, tendo como objetivos o desenvolvimento da indústria de base para a produção de insumos básicos, como metais não-ferrosos, exploração de minérios, petroquímica, fertilizantes, papel e celulose; de infra-estrutura e energéticos, com novas formas de energia, como a nuclear, álcool; e de bens de capital.

Para o cumprimento do plano, a importação de tecnologia se tornou fundamental. Em contrapartida, para compensar o balanço de pagamentos, 0 governo oferecia subsídios ao setor agro-exportador, ampliando as exportações de soja e laranja.

O II PND trouxe avanços à medida que torna o Brasil um dos países mais importantes da América Latina no que se refere ao setor industrial, estendendo o milagre do crescimento até 1980. 


\section{A intervenção do olhar externo na educação brasileira}

Durante a Segunda Guerra, os governos dos países dominantes, em especial dos Estados Unidos, e dos países subordinados estabeleceram entre si novas alianças, acordos, tratados e organizações bilaterais e multilaterais, apoiando-se e fortalecendo-se mutuamente, para fazer frente às tensões e lutas de classe. Essa situação exigiu a reinterpretação das condições de estabilidade social, política e econômica nos países dependentes. O Brasil ingressou nesse esforço doutrinário, buscando adotar todas as diretrizes (lanni, 1988, p.109-10).

Nesse cenário é realizada a I Conferência de Ministros e Diretores de Educação das Repúblicas Americanas, em 1943, cujo objetivo seria planejar "um mundo melhor, baseado na educação e na cultura" (Fonseca, 1961, v1, p.561).

Segundo o engenheiro-educador ${ }^{19}$, a Recomendação de número XV relativa especificamente ao ensino industrial, e a Resolução XXVIII — relativa à educação nas Américas, salientavam que os governos individualmente, ou por meio de convênios, deveriam tomar providências destinadas a elevar o nível educacional, a estender facilidades educacionais e a melhorar, em geral, o papel da educação, como uma contribuição importante para o entendimento e a solidariedade interamericana (ibidem, ibid.).

No Brasil, essa Resolução influenciou o ensino profissional para indústria, levando o então Ministro da Educação e Saúde, Gustavo Capanema, a articular junto a autoridades educacionais norte-americanas, representadas pela InterAmerican Foundation Inc., um programa de cooperação educacional, que seria assinado, em 1946, pelo novo Ministro, Raul Leitão. O acordo tinha o objetivo de promover a aproximação entre os dois países, por meio do intercâmbio de educadores, idéias e métodos de ensino (op. cit.). Tal acordo imputou a criação da Comissão Brasileiro-Americana de Educação Industrial (CBAI) para atuar como órgão executivo na aplicação do citado programa de cooperação educacional, que contaria com a participação de um representante norte-americano - Representante Especial da Inter-American Educational Foundation Inc.

Para tanto, a CBAI estabeleceu 12 pontos de ação a fim de colocar em prática o programa, chegando a debater, com os diretores das escolas federais, assuntos administrativos, escolares e técnicos. Também introduziu no Brasil o método 
Training Within Industry $(\mathrm{TWI})^{20}$ que, de certo modo, influenciou as práticas pedagógicas do ensino profissional para indústria, tal como acontecera na década de 1930, quando Roberto Mange ${ }^{21}$ fundou o Instituto de Organização Racional do Trabalho (IDORT).

A CBAl atuou em vários programas como, estudos e pesquisas relacionados às 'necessidades' educacionais no Brasil, em geral, e do ensino profissional, em particular; treinamento de professores e de técnicos-administrativos para atuarem no ensino industrial, aquisição de equipamentos, etc.

A CBAl é órgão de cooperação entre o Ministério da Educação e Cultura e a Agency for International Development, do Governo dos Estados Unidos da América. Tem por finalidade estreitar a amizade e promover maior compreensão entre os povos dos Estados Unidos do Brasil e dos Estados Unidos da América, favorecer o bem-estar geral e possibilitar atividades educacionais, no setor do ensino profissional do Brasil, através de programas de cooperação, e estimular o intercâmbio de idéias e processos pedagógicos, no campo da educação profissional. A CBAl opera na base de Projetos, que são unidades de trabalho elaboradas e postas em execução mediante acordo entre o Superintendente e o Chefe da Delegação Americana, visando a beneficiar instituições federais, estaduais ou particulares $^{22}$.

O referido acordo assinado entre Brasil e Estados Unidos, na segunda metade dos anos de 1940, pode ser tomado como marco da intervenção do olhar externo na educação brasileira. A partir do Acordo Básico que deu organicidade à CBAI, foram assinados, periodicamente, vários termos aditivos.

Para além da CBAI, vale destacar a Recomendação Internacional sobre Ensino Técnico e Profissional elaborada pela UNESCO, em 1962, que serviu de documento base para os trabalhos da Conferência Geral da Organização das Nações Unidas para a Educação, a Ciência e a Cultura, realizada no mesmo ano, na cidade de Paris. Interessante notar que os termos dessa Recomendação estiveram presentes em documentos emanados não apenas pelo Conselho Federal de Educação (MEC/CFE) na década de 1970, como, também, pela Secretaria de Ensino Médio e Técnico (MEC/SEMTEC) nos anos de 1990, a exemplo do estabelecimento de três níveis de ensino, na formação profissional - "ensino para a formação de trabalhadores qualificados", "ensino para a formação de técnicos" e "engenheiro e 
quadros superiores" - e de sustentar uma relação entre educação e desenvolvimento tecnológico.

Em face dos enormes progressos técnicos que se estão realizando
ou se prevêem em todos os países do mundo, a educação deve
preparar as pessoas para viverem numa era tecnológica ${ }^{23}$ (...) O
ensino técnico e profissional deveria consistir em alguma cousa
mais do que formar alguém para determinado ofício, dando-lhe os
conhecimentos práticos e técnicos necessários. Essa formação
associada à educação geral, deveria contribuir, também, para
desenvolver a personalidade e o caráter do indivíduo e para
estimular a sua capacidade de compreender, de julgar, de discernir
e de adaptar-se às circunstâncias (RECOMENDAÇÃO da UNESCO,
1962 apud Revista Ensino Industrial n. 1, ano 1, nov./1962).

Outro princípio que destaco, refere-se à precípua necessidade de modificar a visão da sociedade, em geral, e da classe média, em particular, sobre o ensino profissional de nível médio, ou melhor dizendo, com o desenvolvimento das forças produtivas em um cenário cujo padrão de acumulação era o taylorista-fordista, amparado pelo welfare state, urgia valorizar o trabalho manual/parcelar: "O ensino técnico e profissional em todos os níveis ${ }^{24}$ deveria insistir em que se reconheça a dignidade do trabalho manual e sua importância nos modernos processos de produção" (ibid., ibid.).

A referida Recomendação da UNESCO, em 1962, ao propor a educação para a vida em uma era tecnológica, parte do pressuposto que ciência e técnica são os fundamentos do desenvolvimento econômico e social, estabelecendo, por conseguinte, que os planos de ensino técnico e profissional destinados a formar pessoal para as áreas da indústria, agricultura, comércio e serviços afins, além de levaram em conta a rápida evolução da tecnologia deveriam, também, elevar o patamar de escolarização, ampliando a formação técnica e profissional ${ }^{25}$. É, pois, no início dessa década que se gesta a concepção de educação tecnológica, desenvolvida historicamente nos anos de 1970 e 1980, cujo ideário amadurecido, no final da década de 1990, promoveu a reforma do ensino profissional de nível médio. O termo 'tecnológica' será vinculado à educação, ganhando fluência nos documentos oficiais do MEC, ao mesmo tempo em que, expressões como, educação técnica e formação técnico-profissional vão, gradativamente, caindo em desuso nos documentos legais da política de formação profissional que passa a 
vincular o termo 'tecnológica' à educação, no sentido de prover o Estado de mão-deobra especializada para a indústria, em particular, instituindo cursos de engenharia de operação, destinados à formação profissional-tecnológica de engenheiros práticos, distintos de engenheiros de maior formação, a profissional científica; além da criação de cursos de tecnólogos de modo a atender os setores primário e terciário, em geral.

\section{O desenvolvimento histórico da concepção de educação tecnológica: dos anos de 1960 a 1980}

Em face das recomendações de organismos internacionais; do desenvolvimento das forças produtivas; da expansão industrial no país; e, ainda, da necessidade de o parque industrial se adaptar às novas tecnologias, a política de formação profissional torna-se mediação no sentido de prover o Estado de mão-deobra especializada. Foi quando, em 1962, o CEF organizou, provisoriamente, os currículos mínimos de cursos de engenharia, deixando em aberto o debate sobre a duração dos cursos, se de e cinco anos ou não (NASCIMENTO, 1986, p. 39).

Assim, o Parecer nำ 60/63 do CFE instituiu o curso de engenharia de operação, com três anos de duração, cujos currículos mínimos foram fixados no Parecer $n$ ำ 25/65, definindo o perfil do engenheiro de operação como "elemento de formação profissional-tecnológica ${ }^{26}$, de nível superior", distinguindo-se de engenheiros com "cursos de formação profissional científica, que não se confundem com os primeiros por exigirem preparação científica muito mais ampla e, em conseqüência, maior duração dos respectivos cursos". A partir de então, não só o referido Parecer $\mathrm{n}^{\circ}$ 25, como, também, outros documentos emanados do MEC aderem à expressão formação profissional-tecnológica; primeiro, por relacioná-la ao desenvolvimento das forças produtivas e, depois, por se referir a cursos enquadrados no ensino superior, oferecendo-Ihes um cunho diferenciado dos cursos técnicos de nível médio tidos, até então, como de formação técnico-profissional.

Desse modo, a formação tecnológica seria mais abrangente que a formação técnico-profissional, e, portanto, associada a um nível maior de conhecimento, envolvendo questões não apenas relacionadas ao desenvolvimento de novas tecnologias, mas, também, voltada para as necessidades do mercado. É o que Ítalo Bologna $^{27}$ busca mostrar no relatório sobre a demanda de mão-de-obra para a 
indústria, em 1964, salientando que além do irrisório número de técnicos industriais diante da crescente demanda do setor produtivo, o que vinha ocorrendo era um processo de desqualificação da mão-de-obra à medida que as empresas investiam em novas máquinas. Essa lacuna estaria sendo preenchida, de um lado, por engenheiros e, de outro, por "agentes de mestria guindados, forçosamente, à posição de técnicos", isso é, os operários estariam sendo empurrados pela mecanização para níveis mais altos de qualificação, ou, em outras palavras, a automatização estaria forçando a "intelectualização da mão-de-obra industrial"28. Em vista de estarem ocorrendo dois deslocamentos de função, um no sentido de baixo para cima, pelo trabalhador com baixo nível de qualificação exercendo a função de técnico; e, outro, em sentido inverso, o engenheiro executando tarefas de técnicos, seria justificável a implantação de cursos de engenharia de operação, "que melhor se chamariam de tecnológicos"29.

Tem-se aí, um explícito exemplo do caráter circular da teoria do capital humano, revelada por Frigotto (2001): a evolução da tecnologia força a elevação do patamar de escolaridade, que por vez, obriga a ampliação da formação profissional (número de matrículas e de cursos), compelindo o desenvolvimento econômico, que investirá em ciência e tecnologia, exigindo elevação do patamar de escolaridade...

Em síntese, em seu relatório, Bologna propunha a expansão de cursos de curta duração, a exemplo dos que já existiam ${ }^{30}$ em Volta Redonda e São Bernardo do Campo, mantidos, respectivamente, pela Escola Fluminense de Engenharia e pela Faculdade de Engenharia Industrial, devendo as instituições ministradoras dos cursos funcionar em estreita articulação com empresas do ramo, que, participando da organização dos currículos, ofereceriam pessoal docente especializado e estágio aos alunos.

No ano do golpe de 1964, foram empreendidas diversas mudanças no âmbito do MEC; assim, "o novo MEC"31, de caráter tecnicista, em menos de um ano, conseguiu dar ao Ministério da Educação e Cultura uma feição nova, ao mesmo tempo em que já apontava para diferenciação entre cursos no ensino superior. Um estaria voltado para as questões práticas e imediatas do setor produtivo e, o outro, de caráter científico e formação sólida, deveria estar voltado para a criatividade, projetos e pesquisa. Entrementes, seria encontrado, não apenas o germe da transformação de escolas técnicas da Rede Federal de Ensino Industrial em Centros 
Federais de Educação Tecnológica, mas, também, a consolidação da 'diferenciação para cima' do ensino.

No âmbito do MEC, as políticas educacionais estavam sendo balizadas pelo acordo MEC_USAID, contando com a cooperação técnica da Fundação Ford, e financiadas pelo BIRD e BID. No que mais me interessa, destaco que a implantação da engenharia de operação se concretizou a partir dos resultados de dois grupos de trabalho. O primeiro formado por professores da ETF da Guanabara ${ }^{32}$, também, membros da equipe MEC-USAID, que contaram, em particular, com a assessoria técnica da Fundação Ford que, à época, destinava parte das doações para o ensino técnico no Brasil. Esse grupo de trabalho, sob forte influência do modelo estadunidense, apontou as escolas técnicas federais como o local mais apropriado à instalação e implementação dos cursos para 'engenheiros tecnológicos'.

Nesse cenário, então, em 1965, o MEC não só autorizou a implantação de cursos de engenharia de operação na ETF da Guanabara em convênio com a Escola de Engenharia da Universidade do Brasil ${ }^{33}$, como, também, recomendou, sob a orientação do segundo grupo de trabalho, a expansão dos cursos em outras escolas técnicas federais ${ }^{34}$.

Em 1969, o Decreto-lei no 547 autorizou a organização e o funcionamento de cursos profissionais superiores de curta duração nas escolas técnicas ${ }^{35}$, em geral, dispensando o convênio com a Escola de Engenharia. No mesmo ano, o Decreto-lei n 796 autorizou, em particular, a criação daqueles cursos nas Escolas Técnicas de Minas Gerais e Paraná.

A partir daí, os cursos industriais básicos, ou ginásios industriais, foram, gradativamente, extintos e, o ensino técnico, com nova roupagem, até então restrito ao ensino médio é elevado ao ensino superior. Inicia-se, dessa forma, a contradição da hoje Rede Federal de Educação Tecnológica. Diferenciada de outras instituições de ensino por oferecer a formação profissional integrada à formação de cultura geral, as instituições da Rede Federal de Escolas Técnicas passam a oferecer, também, o ensino superior. Afinal, seriam elas escolas de nível médio ou de nível superior? No âmbito do MEC, tal contradição será usada ora a favor, ora contra os interesses das referidas escolas.

Ressalte-se que no bojo da reforma universitária do governo militar, em que se expandiam cursos de tecnólogos na rede privada de ensino, com a finalidade não 
apenas de atender os três setores da economia, mas, sobretudo, de conter a entrada da classe trabalhadora no ensino superior de qualidade, foi criada no âmbito do Departamento de Assuntos Universitários do MEC (DAU/MEC) uma comissão para reformular a concepção dos cursos de engenharia no Brasil, com vistas à engenharia de operação, posto que as entidades de classe não reconheciam os egressos desses cursos como engenheiros. Corroborava-se, assim, para a extinção dos cursos de "engenheiros tecnológicos" e o surgimento de outros cursos de menor duração, apenas dois anos, que não requereriam o título de engenheiro ${ }^{36}$. Entrementes, toda política de implantação de cursos superiores nas escolas técnicas federais vinha sendo desenvolvida pelo Departamento de Ensino Médio (DEM) do MEC.

$\mathrm{Na}$ ingerência dos acordos MEC-BIRD, depois de se decidir pela extinção dos cursos de engenharia de operação, diante da resistência de entidades de classe em reconhecerem profissionalmente os egressos dos referidos cursos, foi criado o curso de engenharia industrial, com duração de cinco anos. Todavia, a absorção desses últimos pelas universidades foi rejeitada porque a finalidade da engenharia industrial parecia se ajustar melhor à identidade das escolas técnicas, pois que visa

\begin{abstract}
À formação de um profissional habilitado à supervisão de setores especializados da indústria e encargos normais de produção industrial, caracterizado por uma formação predominantemente prática, necessária à condução dos processos industriais, à gerência ou supervisão das indústrias, à direção da aplicação da mão-deobra, às técnicas de utilização e manutenção de equipamentos, enfim, às atividades normais ou de rotina das indústrias (Parecer $\mathrm{n}^{-}$ 4.434/76, apud Nascimento, 1986).
\end{abstract}

Assim sendo, as escolas técnicas foram incumbidas de adaptar os currículos da extinta engenharia de operação à nova realidade. Em decorrência, sob a supervisão do DAU/MEC, em 1978, as Escolas Técnicas Federais do Rio de Janeiro, Minas Gerais e Paraná, foram transformadas em Centros Federais de Educação Tecnológica $^{37}$.

Na justificativa da transformação das ETFs em CEFETs fica clara a intenção do Grupo de Trabalho ${ }^{38}$, instituído para elaborar a proposta de criação dos Centros de Engenharia, de dar continuidade à política associada e dependente dos 
organismos internacionais. O GT assinala que o Acordo MEC/BIRD, nํㅡ 755/BR, foi articulado para prover cursos de curta duração em diferentes modalidades, de modo a atender a diversificada tecnologia industrial de que tanto o Brasil necessitava para seu desenvolvimento tecnológico. Nesse sentido, o que se pretendia era estabelecer uma política diretiva relacionada ao ensino técnico industrial, com base na necessidade de "mão-de-obra tecnológica"39 em diversos níveis de formação — "é o leque que se vai abrindo, pela exigência maior da expansão da tecnologia"40. $\mathrm{E}$ segue o relatório na defesa da manutenção da oferta de diferenciados cursos, em particular na área das indústrias, privilegiando o de tecnólogos, cujo "habitat natural de funcionamento desses cursos" ${ }^{\prime 41}$ seriam as escolas técnicas federais.

Portanto, é a partir da criação dos Centros Federais de Educação Tecnológica $^{42}$ do Rio de Janeiro, Minas Gerais e Paraná, em 1978, pela Lei Federal n- 6.545, como um modelo de formação de profissionais tecnólogos (em cursos de curta duração) e engenheiros industriais (em cursos com igual duração dos cursos convencionais de engenharia), que começa a clarificar, no país, uma concepção de educação tecnológica. Concepção essa que estabelece a política diretriz de ações futuras do MEC, tomando a técnica, a ciência e a tecnologia não como resultado do trabalho humano para o consumo coletivo ou como bem social, mas, sim, para a produção de lucro a serviço do capital.

Após a criação dos três primeiros CEFETs, devido à crise do capital, entre 1979-82, que evidenciava o esgotamento do padrão de acumulação baseado na produção de bens de consumo, já na vigência do III PND, com o modelo nacionaldesenvolvimentista sendo substituído pela expansão do agronegócio e o terceiro setor entrando em franco crescimento, as ações no âmbito do MEC, se retraíram até o final da primeira metade dos anos de 1980, reconhecendo, apenas, o modelo CEFET como "válido e eficaz", consoante o artigo $3^{\circ}$ o do Decreto $n^{\circ}$ - 87.310/82, regulamentador da Lei $n 0.545 / 78$ de criação dos CEFETs:

Integração do ensino técnico de segundo grau com o ensino superior; ensino superior como continuidade do ensino técnico de segundo grau, diferenciado do sistema de ensino universitário; acentuação na formação especializada, levando-se em consideração tendências do mercado de trabalho e do desenvolvimento; atuação exclusiva na área tecnológica; formação de professores e especialistas para as disciplinas especializadas do ensino técnico de segundo grau; realização de pesquisas aplicadas e prestação de 
serviços; estrutura organizacional adequada a essas peculiaridades e aos seus objetivos.

O referido decreto reedita o conceito de que as escolas técnicas, agora CEFETs, se constituem em instituições de ensino diferenciadas e, portanto, separadas do segmento de educação que leva às universidades. Nesse sentido, vai se gestando a proposta de criar uma rede de educação profissional ${ }^{43}$, separada e paralela da rede 'regular' de ensino, que ganhou corpo no governo FHC e se fortalece no governo Lula da Silva.

$\mathrm{Na}$ segunda metade dos anos de 1980, o governo brasileiro buscou consolidar o "modelo CEFET", criando, em 4 de julho de 1986, o Programa de Expansão e Melhoria do Ensino Técnico (PROTEC) ${ }^{44}$, a partir da consulta realizada no dia "D do MEC"45, em âmbito nacional, destinado a expandir a rede federal de ensino técnico de nível médio. A proposta inicial era a de construir 100 novas escolas técnicas, número logo ampliado para 200; entretanto, a opção foi criar um sistema de escolas técnicas como Unidades de Ensino Descentralizadas (UnED) vinculadas aos CEFETs e ETFs, sistema este inspirado na experiência dos campi universitários. Foram construídas, também, escolas agrotécnicas.

O PROTEC se inscreve nas políticas educacionais de uma conjuntura de redemocratização, trazendo em sua essência o ranço do tecnicismo-produtivista do governo militar,

produz uma forma inversa de apreender o processo de desenvolvimento econômico-social capitalista e nivela realidades profundamente diversas no plano das relações de poder internacional (...) inversão que postula que o progresso técnico base fundamental para o desenvolvimento hoje - ao mesmo tempo amplia a oferta de emprego, e essa ampliação exige, generalizadamente, a ampliação das qualificações (Frigotto; Ciavatta; Magalhães, 2006, p.142).

\section{A concepção de educação tecnológica em sua fase amadurecida: os anos de} 1990

No início dos anos de 1990, a concepção sobre a formação profissionaltecnológica já se encontrava em fase amadurecida; denominada de educação tecnológica, pode ser conceituada como uma educação moderna, capaz de 
acompanhar o desenvolvimento das forças produtivas e, devendo, como dantes, aproximar-se do mercado, de modo a atender os setores primário, secundário e terciário da economia.

Ressalte-se que, por essa época, a rede de escolas técnicas federais e CEFETs já não tem como finalidade precípua formar mão-de-obra para indústria, em particular, mas, sim, ofertar cursos de curta duração, em geral, de modo a atender os setores primário e terciário, posto que a Lei $n^{0} 8.711 / 93$, ao ampliar a atuação do Sistema de Educação Tecnológica para as áreas primárias e terciárias da economia, modificou a identidade das escolas técnicas pertencentes à antiga Rede Federal de Ensino Industrial. Em seu teor, a referida lei promove a substituição dos termos área técnico-industrial (mencionado na Lei $n^{\circ}$ 6.545/78) por área tecnológica.

Entrementes, os aparelhos de hegemonia do Estado vinculados ao capital, como a Confederação Nacional da Indústria (CNI), o Instituto Euvaldo Lodi (IEL), a Federação das Indústrias do Estado de São Paulo (FIESP), Instituto Herbert Levy (IHL) e SENAI, "reclamavam mudanças na educação, sob o argumento das mudanças tecnológicas, centrando seu foco, todavia, na concepção de educação polivalente para um trabalhador multifuncional, adaptado, subserviente ao mercado"46 (Frigotto, 2006, p.40).

Para atender as demandas impostas à nova educação, quais sejam, a de se formar profissionais flexíveis e adaptáveis ao setor produtivo e se reproduzir nas escolas o ambiente empresarial ${ }^{47}$, no âmbito do MEC inicia-se uma reforma administrativa com a criação da Secretaria Nacional de Educação Tecnológica (SENET), como unidade específica e especializada para gerir a educação tecnológica em todos os níveis, posteriormente denominada Secretaria Nacional de Educação Média e Tecnológica (SEMTEC) ${ }^{48}$.

Todavia, desde o final da década de 1980, algumas Escolas Técnicas Federais a exemplo das de Pelotas, Campos, Pará, Pernambuco, Rio Grande do Norte, Mato Grosso, São Paulo, Maranhão e Bahia reivindicavam a sua transformação em CEFETs, enquanto outras pleiteavam o direito de ministrar cursos de nível superior. Lograram êxito, no entanto, as Escolas Técnicas do Maranhão e Bahia, transformadas em CEFETs, respectivamente ${ }^{49}$, em 1989 e 1993. As demais foram transformadas em bloco, juntando-se a todas outras escolas técnicas federais do país, em 1994, pela Lei nº 8.948, de 8 de dezembro, que, por sua vez, também instituiu o Sistema Nacional de Educação Tecnológica. 
A criação desse Sistema baseia-se nas políticas de desenvolvimento de países de primeiro mundo, especialmente os europeus, que atribuem o seu desenvolvimento ao investimento sistematizado na busca e uso intensivo de modernas tecnologias. Identificando semelhanças entre a possibilidade de avanço tecnológico no Brasil e nesses países, os problemas do desenvolvimento nacional estariam também condicionados às políticas de investimento em tecnologias e em formação de mão-deobra especializada para operá-las. Identificou-se, com isso, a necessidade de interligação entre os diversos setores que utilizam e desenvolvem tecnologias de ponta, e aqueles setores mais pobres cientificamente. (Ramos, 1995, p. 167).

Para atender as demandas impostas à nova educação, seria essencial "forte base de sustentação a ser construída por uma sólida educação geral tecnológica, voltada para o preparo de profissionais capazes de absorver, desenvolver e gerar tecnologia" (SENETE, 1991, apud Ramos, 1995, p.167).

$\mathrm{Na}$ voz dos empresários, entretanto, o maior problema da educação tecnológica estava no sistema educacional falho que "não é capaz de maximizar a utilização de sua força de trabalho", por ter-se "afastado das verdadeiras necessidades geradas nas atividades econômicas" ${ }^{50}$. A solução é dada pelo IPEA:

Nada impediria que as escolas técnicas pudessem passar a oferecer cursos de qualificação/treinamento de operários, revertendo a tendência de oferecer, cada vez mais, só cursos de nível secundário, superior e às vezes em nível de pós-graduação. Essa reversão ajudaria, como se procurou mostrar historicamente, a melhoria do diálogo com o setor produtivo (IPEA, p.18).

Sob forte influência do pensamento pedagógico empresarial e de economistas, o MEC busca, então, dar respostas às necessidades do capital, avaliando o modelo CEFET.

De fato, talvez tenha chegado a hora, tão almejada pelos que se têm dedicado ao estudo da problemática da educação tecnológica em nosso país, de se estabelecer uma política educacional que venha integrar devidamente vários setores que tradicionalmente têm permanecido isolados entre si, e cuja interligação poderá proporcionar respostas mais adequadas e rápidas às necessidades e aspirações do desenvolvimento nacional auto-sustentado (Brasil, MEC,1992a, p.4, apud Ramos, 1995, 170).

Este modelo constituído em uma rede de instituições ${ }^{51}$ elevadas a status de nível superior, vinculadas ao Sistema Nacional de Educação Tecnológica, deve 
ser visto como um sistema paralelo alternativo do sistema tradicional que precisará de uma política pública própria, considerando suas peculiaridades e os anseios nacionais de desenvolvimento científico, tecnológico, econômico e social do país" (Brasil, MEC, 1994a, pp. 16 a 17, apud op. cit.).

Estaria, assim, consolidada não apenas a estrutura para a reforma da educação promovida pelo governo FHC (1995-2002), como, também a concepção de educação tecnológica, cujo caráter é contraditório, à medida que é abrangente no sentido de formar profissionais em todos os níveis de ensino direcionados ao mercado de trabalho dos três setores da economia, e, restrita, no sentido de caracterizar-se como um segmento de educação paralelo alternativo ao sistema da educação geral.

Diferentemente da concepção de educação tecnológica em Marx, que busca a unidade entre educação e produção material, que tem em sua essência a unidade de teoria e prática, cujo caráter é de totalidade ou omnilateralidade do homem, que não se limita apenas ao trabalho manual ou apenas ao trabalho intelectual da atividade produtiva, mas que possibilidade a plena e total manifestação de si mesmo, independente das ocupações específicas de um determinado posto de trabalho, na análise documental por mim realizada, fica claro que não só nos debates $^{52}$, como, também, na elaboração de documentos da primeira metade dos anos de 1990, a educação tecnológica passa a ser conceituada como uma educação moderna, capaz de acompanhar o desenvolvimento das forças produtivas e, devendo, por conseguinte, aproximar-se do mercado, cuja concepção é contraditória em sua essência, uma vez que, por um lado, concebe uma formação em sentido lato, associada a um nível maior de conhecimento e envolvendo questões relacionadas ao desenvolvimento de novas tecnologias; e por outro, associa essa mesma formação a cursos aligeirados, de conteúdos fragmentados.

No movimento contraditório do desenvolvimento da técnica, ciência e sociedade, a importância do conhecimento está imbricada com os sentimentos de inovação e invenção do ser humano na direção do avanço tecnológico (Silveira, 2005, p.35-46; 2007, p. 86-100). Inserida nesse movimento, a concepção de educação tecnológica, se por um lado, indica a necessidade de formar trabalhadores com base nos fundamentos científicos; de outro, inscrita no modo de produção capitalista que, historicamente, separa trabalhador e instrumento, expropria seu saber, sua qualificação, o domínio das técnicas, possui a capacidade de promover a 
separação entre trabalhador e conhecimento e ciência socialmente produzidos (op. cit).

É, portanto, essa concepção de educação tecnológica que foi o norte da reforma da educação no país. Tida como redentora da nação, acaba por revelar sua proposta de inserir a população, por meio de vários itinerários formativos, na 'Era do Mercado'. A acepção fundamental desta concepção de educação tecnológica encontra-se na visão neoliberal de mundo voltada para modernização sustentada pelo binômio da competitividade - qualidade e produtividade —, na qual o Estado brasileiro, na busca pela retomada do crescimento econômico, transfere para a individualidade de jovens e trabalhadores a responsabilidade de adquirir competências e habilidades de natureza tanto operacional, quanto conceitual, a fim de se inserirem na empregabilidade. No que mais me interessa, a reforma do ensino médio e técnico mediada pelo Decreto n 2.208/97 manifestou essa concepção de educação na Resolução no 04/99, que instituiu as Diretrizes Curriculares Nacionais para a Educação Profissional de Nível Técnico, analisadas e apreciadas pelo Parecer nํㅜ 16/99.

Como em todo Estado burguês, o comitê político da reforma buscou velar seu caráter coercitivo, oferecendo uma face universalizante e democratizante na elaboração das Diretrizes Curriculares Nacionais para a Educação Profissional, de modo a obter o consenso de professores e gestores de escolas técnicas, em geral, e de CEFETs, em particular.

Durante doze meses, a coerção foi sabiamente combinada com a persuação e o consenso $^{53}$ pela Comissão criada, em outubro de 1998, pela Câmara de Educação Básica do Conselho Nacional de Educação, que realizou várias reuniões com professores e pesquisadores do ensino profissional, entidades de classe e universidades.

No aspecto pedagógico, as Diretrizes Curriculares Nacionais para a Educação Profissional de Nível Técnico retomam a teoria do capital humano sob nova aparência, nova roupagem. Caracterizadas por um conjunto de princípios e critérios, as Diretrizes definiram a metodologia de elaboração dos currículos a partir de competências gerais em vinte áreas profissionais. O Parecer $n \cong 16 / 99$, contraditório em sua essência, busca em linhas gerais, busca redimir a sociedade dos estragos que a Lei $n^{\circ}$ 5.692/71 e o Parecer $n \cong$ 45/72 teriam legado, justificando, assim, a separação entre ensino médio e técnico. 
É preciso alterar radicalmente o panorama atual da educação profissional brasileira, superando de vez as distorções herdadas pela profissionalização universal e compulsória instituída pela Lei Federal

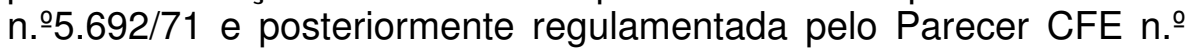
45/72. Essa legislação, na medida em que não se preocupou em preservar uma carga horária adequada para a educação geral a ser ministrada no então segundo grau, facilitou a proliferação de classes ou cursos profissionalizantes soltos tanto nas redes públicas quanto privadas de ensino (...) A separação entre educação profissional e ensino médio, bem como a rearticulação curricular recomendada pela LDB, permitirão resolver as distorções apontadas (BRASIL, MEC/CNE, Parecer no 16, de 1999).

Desse modo, o referido parecer atribuiu às Diretrizes Curriculares para a Educação Profissional o significado de tábula de salvação do planejamento educacional, mostrando uma de suas contradições, uma vez que, ao sustentar a organização curricular no binômio qualidade e produtividade, na busca de uma educação profissional eficiente, acaba por desorganizar as práticas escolares com currículos modularizados, fragmentados e cursos de duração flexível.

A duração da educação profissional de nível técnico, para o aluno, dependerá: a) do perfil profissional de conclusão que se pretende e das competências exigidas, segundo projeto pedagógico da escola; b) das competências constituídas no ensino médio; c) das competências adquiridas por outras formas, inclusive no trabalho. Assim, a duração do curso poderá variar para diferentes indivíduos, ainda que o plano de curso tenha uma carga horária mínima definida para cada qualificação ou habilitação profissional, por área profissional (op.cit.).

Nesse sentido, o aproveitamento de estudos é encarado de modo bem amplo, permitindo ao estudante transitar por várias instituições de ensino, como, também em outros espaços de educação não-formal.

O diploma de uma habilitação profissional de técnico de nível médio, portanto, pode ser obtido por um aluno que conclua o ensino médio e, concomitante ou posteriormente, tenha concluído um curso técnico, com ou sem aproveitamento de estudos. Esse curso pode ter sido feito de uma vez, por inteiro, ou a integralização da carga horária mínima, com as competências mínimas exigidas para a área profissional objeto de habilitação, poderá ocorrer pela somatória de etapas ou módulos cursados na mesma escola ou em cursos de qualificação profissional ou etapas ou módulos oferecidos por outros estabelecimentos de ensino, desde que dentro do prazo limite de cinco anos (ibid.). 
Ressalte-se que, à medida que o capital assume novas formas de organização no processo de acumulação, a burguesia brasileira amolda o Estado às suas necessidades, tornando-o um instrumento a favor dos interesses capitalistas. Assim sendo, a presença do capital humano reforça a necessidade de o Estado reformar o sistema educacional na retomada do crescimento econômico e da modernização. O discurso, expresso nos documentos supracitados, de formar sujeitos polivalentes, flexíveis, colaboradores e participativos e, ainda, adaptáveis ao mercado, evidencia o fator econômico da educação tecnológica.

A educação passa a ser evocada como um instrumento de modernização - o fator preponderante, para a diminuição das 'disparidades' regionais. O equilíbrio, entre as regiões subdesenvolvidas, não-desenvolvidas, em desenvolvimento e desenvolvidas - se daria mediante a modernização dos fatores de produção, especialmente pela qualificação da mão-de-obra (Frigotto, 2001, p.128-9).

Permeado de contradições, o Parecer nำ16 continua na sua apreciação sobre as Diretrizes Curriculares buscando fazer uma inversão da realidade, ao afirmar que reconhece as diferenças de importância atribuídas às tarefas produtivas como, também, a forma hierarquizada da divisão técnica do trabalho, propondo, então, que a educação profissional tome a direção de criticar a distinção social originada por aquela divisão do trabalho. Portanto, para o documento, não é a dualidade de classes originada pela propriedade privada que engendra a divisão técnica e hierarquização do trabalho, mas, sim, o contrário. Segundo o Parecer $\mathrm{n} \cong 16$, essa desigualdade só teria fim com o advento "da sociedade da informação".

Numa visão prospectiva, a política da igualdade deve tornar presente na pauta de toda instituição ou programa de preparação profissional que na sociedade da informação a divisão entre trabalho manual e intelectual, entre concepção e execução tende a desaparecer ou a assumir outras formas. Mesclam-se numa mesma atividade a dimensão criativa e executiva do trabalho; mudam as pessoas ou posições em que se executam ora uma ora outra; um mesmo profissional é convocado tanto para ser criativo como para ser operativo e eficiente. Esse padrão, ainda insinuado, tenderá a ser hegemônico. Portanto a política da igualdade na educação profissional terá que buscar a construção de uma nova forma de valorizar o trabalho, superando preconceitos próprios das sociedades pré-industrial e industrial contra o trabalho manual e as tarefas consideradas inferiores (BRASIL, MEC/CNE, Parecer no 16 de 1999). 
A política da igualdade expressa no documento se pauta no direito à educação, devendo concretizar-se em situações e meios de aprendizagem eficientes, que assegurem a todos a constituição de competências laborais relevantes, num mundo do trabalho cada vez mais competitivo e em permanente mutação. Segue o documento, propondo que seja superada a concepção de educação profissional assistencialista e economicista, marcada pela sociedade industrial repleta de "discriminações e privilégios no âmbito do trabalho". Por conseguinte, a educação profissional deve promover "a constituição de valores de mérito (sic), competência e qualidade de resultados para balizar a competição no mercado de trabalho" (ibid.).

Em outras palavras, o Parecer $\mathrm{n}-16$, ao fazer o vínculo estreito entre educação e modernização, entre educação e desenvolvimento econômico, rejuvenesce o capital humano ${ }^{54}$, agora detentor de competências e habilidades, em um contexto em que a democratização do acesso à educação profissional torna-se mecanismo para justificar as desigualdades sociais, a distribuição de renda e emprego e, ainda, a mobilidade social interclasse.

\footnotetext{
A questão das desigualdades sociais, dos antagonismos de classes, o conflito capital-trabalho seriam superados, por um processo meritocrático. Mascara-se o caráter orgânico da acumulação, concentração e centralização do capital e a própria luta de classes, na medida em que se nivela, sob a categoria de capital, a capacidade de trabalho dos indivíduos, 'potenciada' com educação ou treinamento, ao capital físico, ou seja, a força de trabalho se apresenta como uma mercadoria - um capital do mesmo valor que o capital físico (Frigotto, 2001, p.126).
}

Uma vez que, na contemporaneidade as relações entre trabalho produtivo e improdutivo, manual e intelectual, material e imaterial permitem maior inter-relação, maior interpenetração, entre as atividades produtivas e as improdutivas, entre as atividades fabris e as de serviço, entre as atividades laborativas e as atividades de concepção, produção e conhecimento científico. Entretanto, o capital e sua lei do valor necessitam cada vez menos do trabalho estável e cada vez mais de diversificadas formas de trabalho parcial, terceirizado, que são, em escala crescente, parte constitutiva do processo de produção capitalista (Antunes 2003). Nesse sentido, 
O desenvolvimento de competências profissionais deve proporcionar condições de laborabilidade, de forma que o trabalhador possa manter-se em atividade produtiva e geradora de renda em contextos sócio-econômicos cambiantes e instáveis. Traduz-se pela mobilidade entre múltiplas atividades produtivas, imprescindível numa sociedade cada vez mais complexa e dinâmica em suas descobertas e transformações. Não obstante, é necessário advertir que a aquisição de competências profissionais na perspectiva da laborabilidade, embora facilite essa mobilidade, aumentando as oportunidades de trabalho, não pode ser apontada como a solução para o problema do desemprego (BRASIL, MEC/CNE, Parecer $n^{\circ} 16$ de 1999).

Contraditoriamente, como o capital não pode prescindir do trabalho vivo no processo de criação de valores, passa a aumentar o uso e a produtividade do trabalho de modo a aumentar a mais-valia em tempo cada vez menor. Pretendo dizer com isso que as novas formas de sociabilidade do capital tanto no que se refere ao novo padrão de acumulação, quanto no que se refere à reinserção da classe trabalhadora na nova divisão internacional do trabalho requerem a "valorização do trabalhador".

Nesse contexto, a concepção de educação tecnológica com sua proposta de cursos aligeirados e de conteúdos fragmentados, na realidade concreta, tem a finalidade de formar o "cidadão produtivo" com vistas ao mercado, "no qual o termo produtivo se refere ao trabalhador mais capaz de gerar mais-valia - o que significa submeter-se às exigências do capital que vão no sentido da subordinação e não da participação para o desenvolvimento de todas as suas potencialidades" (Frigotto; Ciavatta, 2006, p.63).

Concordo, pois, com Ramos (2004, p.41), que o entendimento de trabalho explicitado nas Diretrizes Curriculares mostra a concepção de educação do MEC eivada de contradições entre capital e trabalho: ora o trabalho é tomado como princípio vital, ora o trabalho é mercadoria; ora o trabalho é mediação, ora o trabalho é visto como fim no mercado; ora o trabalho é práxis humana, ora o trabalho é práxis produtiva capitalista.

Todo esse arsenal político-ideológico e teórico que foi se produzindo historicamente, durante décadas, marcado por contradições entre capital e trabalho, e que culminou na reforma do ensino médio e técnico dos anos de 1990, refletiu-se internamente no cotidiano de escolas técnicas e CEFETs, "por ter sido um processo 
no qual as escolas tiveram que se inserir, sem a opção do contrário, suas identidades foram afrontadas por um projeto não construído por elas próprias, mas por sujeitos externos"(Ciavatta, 2005, p.98).

\section{Considerações finais}

Historicamente, a partir do desenvolvimento da maquinaria, o modo de produção capitalista separa, cada vez mais, ciência e técnica, trabalho manual e trabalho intelectual, trabalho material e trabalho imaterial, e ainda, sob estas condições, trabalho e trabalhador são subsumidos às leis imanentes do capital acumulação, concentração e centralização.

Assim sendo, constata-se que na luta histórica travada entre capital e trabalho, a educação - entendida, por mim, como processo na perspectiva da luta emancipadora, e, tal como o trabalho, deve ser atividade humana auto-realizadora, prática sociopolítica definida no seio das relações sociais - responde predominantemente aos interesses imediatos do capital, reduzindo-se, fundamentalmente, à formação da força de trabalho como capital humano. Nessa dimensão, a educação deixa de ser processo, sendo reduzida a doses homeopáticas de qualificação e requalificação, vistas como geradoras de maior produtividade, que, por sua vez, eleva o crescimento econômico do país, pretendido por um Estado em busca da modernização e da competitividade.

No Brasil, a concepção de educação voltada para a formação do trabalhador, em geral, e de educação tecnológica, em particular, vem reunindo, desde os anos de 1960, um conjunto de ações em torno da política educacional, atrelando, cada vez mais, não apenas a educação ao desenvolvimento econômico como, também, voltando a escola do trabalho para as necessidades estritas do mercado. Neste cenário, o trabalhador é visto tão somente como fator da produção.

O Estado em busca da modernização, mediado pelo MEC, enfatizou a política de "formação e valorização do trabalhador" como estratégia de competitividade, qualidade e produtividade para os três setores da economia. A concepção de educação tecnológica, fundamentada em uma perspectiva economicista, revestiu o "capital humano" com uma roupagem - "humanista e humanizadora" —, trazendo preocupações marcantes com a valorização das competências, autonomia, participação, flexibilização do trabalhador devidamente (con)formado.

Por detrás dessa "formação e valorização do trabalhador" está o individualismo leonino ${ }^{55}$ da ideologia neoliberal, em que o Estado brasileiro, na 
busca pela retomada do crescimento econômico, transfere para a individualidade de jovens e trabalhadores a responsabilidade de adquirir competências e habilidades, ter iniciativa própria e capacidade de resolver problemas, ter criatividade, autonomia e espírito empreendedor, a fim de se inserirem na empregabilidade, em um contexto de precarização do trabalho.

Ressalto que, nos de anos 1990, no contexto da reestruturação produtiva no Brasil, o aparato científico e tecnológico ajustado ao modelo desenvolvimentista de substituição de importações fora desmontado, criando-se, a partir de então, o Programa de Apoio Científico e Tecnológico da Indústria (PACTI) e o Programa Brasileiro de Qualidade e Produtividade (PBQP) vinculados ao Ministério de Ciência e Tecnologia e ao Ministério da Economia, respectivamente, com a finalidade de traçar as diretrizes da política científica e tecnológica segundo os preceitos neoliberais. Além do que, o programa de governo de $\mathrm{FHC}$ - Mãos à Obra Brasil: proposta de governo - teve a educação como uma de suas cinco metas prioritárias, além da agricultura, emprego, saúde e segurança, sustentando-se fundamentalmente na perspectiva do desenvolvimento econômico brasileiro, em um mundo globalizado e de internacionalização dos processos de produção caracterizados pela revolução científico-técnica, como mote da competitividade.

Desse modo, a educação torna-se mediação para implementar o programa, o que exigiu uma profunda reforma no sistema educacional brasileiro, atribuindo à educação o papel de mola propulsora para alcançar o desenvolvimento e impulsionar inadiáveis transformações sociais, com o objetivo de levar o Brasil a ocupar uma posição de destaque no cenário da economia mundial (Santos, 2006, p. 74-5).

No que refere a reforma curricular empreendida nos cursos técnicos nas escolas da Rede Federal de Educação Tecnologia, em geral, foram tomadas iniciativas que tornaram-se sustentáculo da política de educação, refletindo-se de modo mediato e imediato na reformulação curricular. Desse modo, a política governamental de Fernando Henrique Cardoso lançou mão do caráter circular da teoria do capital humano - a evolução da tecnologia força a elevação do patamar de escolaridade que, por sua vez, obriga a ampliação da formação profissional, compelindo, assim, o desenvolvimento econômico, que investirá em ciência e 
tecnologia, exigindo elevação do patamar de escolaridade... - e, sob o discurso de investir em infra-estrutura, promoveu a reforma curricular do ensino médio e técnico.

Separando o ensino médio do ensino técnico, obrigou escolas técnicas e CEFETs a ampliar o número de matrículas, por meio da implantação de cursos cuja a finalidade é (con)formar trabalhadores para atuar no mercado de trabalho de um país desindustrializado e desnacionalizado ${ }^{56}$. Neste sentido, posso afirmar que os processos de desindustrialização e desnacionalização promovidos pelo governo FHC, influenciaram sobremodo a reforma curricular dos cursos técnicos.

A formação profissional aligeirada, devido à redução de carga horária dos cursos ministrados, à pouca quantidade de aulas práticas, à insuficiente articulação entre teoria e prática, à redução da ênfase em conteúdos específicos, entre outros aspectos, revela que a reforma da educação profissional implantada é de base tecnicista e instrumental.

Para além dos currículos fragmentados, de carga horária restrita, da separação entre ensino técnico e médio, que acabou por reduzir a qualidade do ensino, o resultado da política governamental se traduziu, também, na superelevação dos índices de evasão nos cursos técnicos. NO CEFET/RJ, em particular, o percentual de evasão, visto a partir do número total de alunos matriculados nos cursos técnicos, varia entre 41,97\% e 70,29\%; entretanto, se entrarmos nas especificidades dos cursos, o percentual chega a 87,04\% (SILVEIRA, 2007, p. 236-253).

Cabe repetir, mesmo sob pena de ser redundante, que diferentemente da concepção de educação tecnológica em Marx e da concepção da escola única de Gramsci que buscam a unidade entre educação e produção material, que tem em sua essência a unidade de teoria e prática, cujo caráter é de totalidade ou omnilateralidade do homem, não limitado apenas ao trabalho manual ou apenas ao trabalho intelectual da atividade produtiva, mas sim, a possibilidade de uma plena e total manifestação de si mesmo, independente das ocupações específicas de um determinado posto de trabalho; a concepção de educação tecnológica das reformas educacionais, no Brasil, é contraditória em sua essência, à medida que, por um lado, concebe uma formação em sentido lato, associada a um nível maior de conhecimento e envolvendo questões relacionadas ao desenvolvimento de novas tecnologias e, de outro, associa esta mesma formação a cursos aligeirados, de 
conteúdos fragmentados. Neste sentido, conceitua-se a educação tecnológica como uma educação moderna, capaz de acompanhar o desenvolvimento das forças produtivas e, devendo, por conseguinte, aproximar-se do mercado, ou em outras palavras, uma educação que atende aos interesses do capital.

O resultado desse processo histórico define não só o tipo de sociedade vivida pelos brasileiros, constituída nos planos da estrutura econômico-social e superestrutura jurídico-político-ideológica na sua relação com o interno e o externo, mas, também, o estágio de desenvolvimento tecnocientífico que expressa sua posição/situação na divisão internacional do trabalho e suas implicações com as demandas do trabalho - uma sociedade dividida entre 0 tradicional/atrasado/subdesenvolvido e o moderno/desenvolvido, cindida em classes, fonte da expropriação do trabalho.

\section{NOTAS}

* Este texto tem por base Silveira, 2007. Ressalvo aqui, meus respectivos textos publicados ou para publicação.

** Doutoranda em Educação (UFF), Mestre em Educação (UFF), Professora do Curso Técnico de Segurança do Trabalho do CEFET/RJ.

1 - O legado do governo militar à Nova República foi o de um quadro educacional funesto: aproximadamente $30 \%$ da população era analfabeta; o índice de evasão e repetência aproximava-se de $50 \%$; $23 \%$ dos professores eram leigos. Com estes índices, o Brasil integrou o grupo dos países com maior taxa de analfabetismo (E-9), na Conferência de Jomtien, tendo que se comprometer a promover políticas públicas de educação a partir do Fórum Consultivo Internacional de Educação para Todos.

2 - Para maiores detalhes, consultar www.unesco.org.br/publicações. Interessante verificar a relação entre esse documento e o produzido na década dos anos de 1970, citado por mim, anteriormente.

3 - Vale conferir "Os arautos da reforma entre os educadores" em Shiroma, 2000, p.82 -86.

4- No compromisso coletivo ficou acordado que para se atingir os objetivos e metas, "portanto, é essencial que novos compromissos financeiros concretos sejam firmados pelos governos nacionais e também pelos doadores bilaterais, multilaterais, incluindo-se o Banco Mundial, os bancos regionais de desenvolvimento, a sociedade civil e as fundações", 28 de abril de 2000, Dakar, Senegal.

5 - CUNHA, Luiz Antonio. O ensino superior no octênio FHC. Revista Educação \& Sociedade, v.24, n. 82. Campinas, 2003. Disponível em:

http://www.scielo.br/scielo.php?script=sci arttext\&pid=S0101-73302003000100003\&lng=pt\&nrm=iso 
6 - O Exame Nacional de Curso (ENC), denominado provão, foi criado em 1996, para avaliar a qualidade dos cursos de graduação; aplicado aos formandos, e de caráter obrigatório, foi substituído em 2004 pelo, então, Exame Nacional de Desempenho dos Estudantes (ENADE).

7- O nacionalismo, fruto do Estado desenvolvimentista no Brasil, identifica-se com o autoritarismo por estar relacionado à construção da idéia de nação que surge com a Revolução de 1930 em confronto com as idéias liberais (Barreto, 2000, p. 39).

8 - O Estado autoritário onipresente das décadas de 1930 e 1940 já é "desenvolvimentista", embora esse epíteto seja a ele associado em geral na literatura a partir dos anos de 1950, quando se acelera expressivamente a industrialização (ibidem, p. 38). Nesse estudo, identificaremos o Estado NacionalDesenvolvimentista como provedor da industrialização no Brasil, no período de 1930-1979.

9 - "No Brasil foi feita uma distinção entre nacionalismo "de direita" e nacionalismo "de esquerda". Ele [o de esquerda] fez parte da ideologia da corrente verde-amarela dos anos 30 cujos membros (Plínio Salgado, Cassiano Ricardo, Menotti del Picchia) serão futuros adeptos do integralismo. Os nacionalistas de filiação autoritária [de direita] (Alberto Torres, Oliveira Viana) vão sempre repetir que liberalismo é produto importado, inadaptável ao Brasil" (Barreto, 2000, p.40).

10 - Diferentemente das demais instituições que tinham por finalidade um país capitalista desenvolvido, O PCB tinha a finalidade de romper os grilhões da dependência, rumo ao socialismo, por meio da revolução burguesa.

11 - A indústria natural utilizava matéria-prima nacional, enquanto que a indústria artificial lançava mão de matéria-prima importada (Barreto, 2000, p.43).

12 - Para maiores detalhes ver Carvalho (2004).

13 - A respeito dos antecedentes históricos do surgimento das teorias sobre desenvolvimento, ver Dos Santos Theotonio. La teoria de la dependência: um balance histórico y teórico. In: Segkeka, Francisco Lopes (Ed). Los rell de la globalización. Ensayos em homenage a Theotonio dos Santos. Tomo I. Caracas: Unesco, 1998.

14 - O BNDE, hoje BNDES, foi criado pela Comissão Mista Brasil-Estados Unidos, vinculada ao Plano Americano de Ajuda Técnica para as áreas da defesa, da educação, da saúde, da agricultura e do planejamento econômico, como órgão técnico para promover o desenvolvimento de setores básicos da economia, nas esferas pública e privada.

15 - Neto, Desmostenes Pinho, 1989, apud Barreto, 2000, p.52.

16 - A instrução no 113, expedida no governo interino de Café Filho e mantida pelo governo JK, exalta o imperialismo. Para maiores detalhes, ver Marini (2000). 
17 - Centro Pesquisa e Documentação de História Contemporânea do Brasil. Disponível em http://www.cpdoc.fgv.br/comum/htm/. Acesso em novembro de 2006.

18 - O convênio com o FMI, assinado em maio de 1946, no governo de Eurico Dutra, não permitia a existência de moedas flutuantes, nem a introdução de depreciações unilaterais para aumentar a competitividade. Dutra manteve-se atrelado a esse princípio durante todo seu período constitucional, mesmo em face de desvalorizações "ilegais" realizadas por alguns países europeus durante a fase de queda do dólar no imediato pós-guerra. A declaração de paridade da moeda brasileira, em meados de 1946, quando da paridade entre ouro e dólar, correspondia a uma taxa de Cr\$18,46 por dólar, foi mantida até o Governo Vargas, quando foi promovida a reforma cambial. A primeira operação contraída pelo Brasil com uma das organizações de Bretton Woods - o Banco Mundial - foi um empréstimo para um projeto de energia elétrica à base térmica, em 1949, por um montante de 75 milhões de dólares. As operações com o FMI não começaram de outro modo na década seguinte. A primeira experiência teria sido um simples aval dado, em 1954, a empréstimo do Eximbank, o banco garantidor de financiamentos às exportações do governo americano, o que foi logrado a despeito do sistema de taxas múltiplas de câmbio então mantido pelo Brasil (Almeida, Paulo Roberto de. O Brasil e o FMI de 1944 a 2002: um relacionamento feito de altos e baixos. Disponível http://www.anpuh.uepg.br/hissoria-hoje/vol1n1/brasilfmi.htm. Acesso em 19/01/2007.

19 - Parafraseio Rodrigues (2002).

20 - O método TWI foi lançado nos Estados Unidos, em 1940, com a finalidade de qualificar trabalhadores para o processo produtivo, de modo a torná-los mais engajados com o aumento da produtividade e reduzir os custos do produto final.

21 - Mange destacou-se, entre outros engenheiros, na divulgação da doutrina sistematizada por Frederick Taylor - Organização Racional do Trabalho - , criando o IDORT, em 1931, sob o patrocínio da Associação Comercial e da Federação das Indústrias. A participação de Mange será também decisiva, atuando como consultor junto à comissão organizadora da Lei Orgânica do ensino industrial e na criação do SENAI. Para maiores detalhes ver "A montagem do Senai" em Cunha, 2000, e, ainda, Rodrigues (1998).

22 - Revista Ensino Industrial. Brasília: MEC/CBAI/DEI, n. 1, ano 1, nov. /1962.

23 - O termo tecnológica além de marcar um padrão de desenvolvimento da sociedade, será atrelado à educação de modo a valorizar essa última no sentido de acompanhar o seu tempo de desenvolvimento econômico, produção de bens de capital, e qualidade de produtos.

24 - Interessante notar que, em fevereiro de 1963, o Conselho Federal de Educação aprovou o parecer que originou os cursos de engenharia de operação. Como se sabe, essa modalidade de ensino destinava-se a formação de engenheiros voltada para atividades práticas, enquanto que o trabalho intelectual (planejar e projetar) ficava a cargo de engenheiros com formação plena.

25 - Lembro que a formação técnica profissional, proposta pelo documento, abrangia três níveis de ensino: qualificação, formação de técnicos e engenheiros. 
26 - Grifos meus.

27 - Ítalo Bologna faz parte de uma geração de engenheiros-educadores, dentre os quais se destacam Celso Suckow da Fonseca, Francisco Montojos, João Lüderitz e Roberto Mange. Ítalo Bologna atuou no IDORT, no Centro Ferroviário de Ensino e Seleção Profissional (CFESP) e, ocupou alguns cargos, no SENAI. À época em que escreve o citado relatório, Bolonha ocupava o cargo de Assessor da Presidência da FIESP, passando, mais tarde, a Diretor Nacional do SENAI (FRIGOTTO e RODRIGUES, 2002).

28 - BOLOGNA, Ítalo. Demanda de mão-de-obra especializada no atual surto industrial brasileiro. In: MEC/CBAI/DEI. Revista do Ensino Industrial, n. 9, ano III, dez./1964.

29 - Ibidem.

30 - No final da década de 1960 foram criados os cursos de tecnólogos no Centro Estadual de Educação Técnica do Estado de São Paulo e no Centro de Educação Técnica da Amazônia, hoje Centros de Educação Tecnológica. No contexto da reforma da educação do final dos anos de 1990, a política educacional do governo FHC supervaloriza esses cursos de curta duração, mudando sua nomenclatura para Cursos Superiores de Tecnologia e promovendo sua expansão tanto na rede privada, quanto na rede pública de ensino.

31 - "O novo MEC em menos de um ano conseguiu dar ao Ministério da Educação e Cultura uma feição nova, reorganizando os seus serviços e transformando os processos de administração (...) como uma máquina, cujas peças estão bem ajustadas - o desgaste é menor e é mais rendosa a produção". Revista do Ensino Industrial. MEC/CBAI/DEI, n. 9, ano III, dez./1964.

32 - O hoje Centro Federal de Educação Tecnológica Celso Suckow da Fonseca (CEFET/RJ).

33 - O convênio foi celebrado em virtude de a ETF da Guanabara ter status de escola de nível médio.

34 - Além de implantados na ETF da Guanabara, os cursos de engenharia de operação também foram ministrados na ETF da Bahia, ETF de Minas Gerais e ETF do Paraná.

35 - Nesse contexto, em 1971, é assinado o acordo MEC/BIRD, um convênio "guarda-chuva", para se colocar em prática a reforma educacional do governo militar. O órgão executor, o PRODEM (Programa de Desenvolvimento do Ensino Médio e Superior de Engenharia de Operação), levou 9 anos para realizar o projeto, contando, inicialmente, com 21 milhões de dólares do BIRD, para construir prédios; equipar oficinas e laboratórios; capacitar "recursos humanos", em todos os níveis (NASCIMENTO, 1986, p.44-5).

36 - Nascimento (1986). 
37 - Sobre o processo de transformação das escolas técnicas em CEFETs, ver Campello (2005).

38 - O GT foi formado pelos professores Máximo Ivo Domingues, representante da Secretaria Geral do MEC e coordenador do Grupo de Trabalho; Osvaldo Vieira Nascimento, representante do DAU/MEC, ex-integrante do PRODEM, pertencente ao quadro de professores da ETFCSF; Hélio Gelape, representante do DEM/MEC, professor da ETF de Minas Gerais; Carlos Magno Pereira representante do PRODEM, professor da ETFCSF.

39 - Relatório do GT para "estudar a criação dos Centros de Engenharia" (NASCIMENTO, 1986, p.49-50).

40 - Ibid., p.51.

41 - Ibid., ibid.

42 - Segundo Nascimento (1986), a estrutura administrativa dos três CEFETs teve como paradigma o Centro de Educação Tecnológica da Bahia, criado em 1976, nas dependências da Escola Técnica Federal da Bahia, exclusivamente para ministrar cursos de tecnólogos.

43 - A expressão Educação Profissional ganha fluência na política educacional do ministério de Paulo Renato, no governo FHC. O primeiro projeto de LDB apresentado na Câmara Federal, em 1988, no Capítulo III, o Da Educação Escolar de 20 grau, tinha como objetivo geral da educação de 20 grau a formação politécnica. Após sofrer várias alterações, o substitutivo de Jorge Hage incorpora ao texto um capítulo específico, o Da formação técnico-profissional; esse capítulo tem sua nomenclatura modificada no substitutivo de Darcy Ribeiro (95/96) para Educação Profissional, sendo, então, transformada em uma modalidade de educação, distinta e separada do então ensino regular - a Educação Básica.

44 - Para maiores detalhes ver FRIGOTTO, FRANCO e MAGALHÃES, 2006.

45 - O Dia D, ocorrido em setembro de 1985, foi o dia em que todas as escolas, em âmbito nacional, suspenderam suas atividades de aula, para debater a educação no país. Promovido pela SEPS/MEC, a oficina, cujo tema foi Educação e democracia, tinha o objetivo de discutir a política educacional no país, em geral, e o trabalho pedagógico das escolas, em particular. "Muitos foram os pontos levantados durante as discussões: do livro didático às condições físicas das escolas; da competência técnica dos educadores à política social do Governo; dos conteúdos estudados às condições socioeconômicas da população estudantil (...)". CEFETBA. Disponível em http://www.cefetba.br/comunicacao/parte1.html. Acesso em agosto de 2006.

46 - A esse respeito, vale conferir o documento produzido a partir da Reunião de Presidentes de Organizações Empresarias IberoAmericanas, intitulado Educação básica e formação profissional - uma visão dos empresários. Rio de Janeiro, CNI, 1993. 
47 - Segundo Ramos (1995), uma das medidas tomadas nesse sentido foi a criação do Núcleo de Qualidade Total do MEC, exigindo que todas as escolas instituíssem seu próprio núcleo, de modo a implementar a gestão da qualidade total.

48 - A dualidade estrutural da educação expressa na forma da lei, no governo Cardoso, que obrigava a separação do ensino médio e do ensino técnico, torna-se mais visível no governo Lula da Silva, com a transformação administrativa da SEMTEC em duas secretarias: Secretaria de Educação Profissional e Tecnológica (SETEC) e Secretaria de Educação Básica (SEB).

49 - Lei nํ7863/1989 e Lei no 8711/1993.

50 - CNI. Competitividade Industrial - uma Estratégia para o Brasil (1988), apud Rodrigues (1998).

51 - Atualmente, essa rede é formada por 152 escolas: 36 Agrotécnicas Federais (EAF); 34 Centros Federais de Educação Tecnológica (CEFETs) com 44 Unidades Descentralizadas (UnEDs); 32 Técnicas vinculadas às universidades federais; 1 Escola Técnica Federal e 1 Universidade Tecnológica (UT) com 6 UnEDs. BRASIL/MEC. Disponível em: http://portal.mec.gov.br/setec/. Acesso em 10/01/2007.

52 - Sobre os debates reivindicatórios da cefetização de todas as escolas técnicas efetivada pela Lei no 8.948/94, Ramos (2006, p.289) destaca que a efetiva transformação das escolas técnicas em CEFETs se deu , apenas, em 1997, após a adesão formal dos diretores-gerais daqueles instituições à reforma do ensino médio e técnico promovida pelo Decreto no 2.208/97. Entretanto, cabe ressaltar que, a partir do I Encontro Nacional de Departamentos de Ensino de ETFs e CEFETs, algumas instituições em busca de elevar seu status, a exemplo da Escola Técnica Federal do Rio Grande do Norte, já apresentavam propostas de reformulação curricular que iam ao encontro dessa concepção de educação tecnológica.

53 - Gramsci, 2001,v.4, p.273.

54 - Parafraseio Frigotto (2003), em Educação e a crise do capitalismo real.

55 - Para maiores detalhes ver SILVEIRA, Zuleide Simas da. Contradições entre capital e trabalho: concepções de educação tecnológica na reforma do ensino médio e técnico. Dissertação (Mestrado em Educação) - Universidade Federal Fluminense, Niterói, Rio de Janeiro, 2007. Disponível em:

http://www.uff.br/pos educacao/joomla/images/stories/Teses/zuleidesilveira07.pdf.

56 - O processo de desnacionalização da economia bem como 0 de desindustrialização foram analisados no meu trabalho de dissertação. Cf. SILVEIRA, Zuleide Simas da. Contradições entre capital e trabalho: concepções de educação tecnológica na reforma do ensino médio e técnico. Dissertação (Mestrado em Educação) - Universidade Federal Fluminense, Niterói, Rio de Janeiro, 2007. Disponível em:

http://www.uff.br/pos educacao/joomla/images/stories/Teses/zuleidesilveira07.pdf. 


\section{REFERÊNCIAS BIBLIOGRÁFICAS}

ANTUNES, Ricardo. Os sentidos do trabalho: ensaio sobre a afirmação e a negação do trabalho. 6. ed. São Paulo: Boitempo, 2003.

BARRETO, Helena Motta Salles. Crise e reforma do Estado Brasileiro. Juiz de Fora: EdUFJF, 2000.

BRANDÃO, Octávio. Agrarismo e industrialismo: ensaio marxista-leninista sobre a revolta de São Paulo e a guerra de classes no Brasil - 1924. São Paulo: Anita Garibaldi, 2006.

BOITO Jr., Armando. Hegemonia neoliberal e sindicalismo no Brasil. Revista Crítica Marxista, $\quad$ n. $\quad 3, \quad 1996 . \quad$ Disponível em http://www.unicamp.br/cemarx/criticamarxista/sumario3.html

BOLOGNA, Ítalo. Demanda de mão-de-obra especializada no atual surto industrial brasileiro. In: MEC/CBAI/DEI. Revista do Ensino Industrial, n. 9, ano III, dez./1964.

BRASIL. Decreto $n^{\circ} 2.208$, de 17 de abril de 1997. Regulamenta o $\S 2^{\circ}$ do art. 36 e os arts. 39 a 42 da Lei no 9.394, de 20 de dezembro de 1996, que estabelece as diretrizes e bases da educação nacional.

BRASIL. Decreto $n^{\circ} 2.406$, de 27 de novembro de 1997. Regulamenta a Lei $n^{\circ}$ 8.948, de 8 de dezembro de 1994, e dá outras providências.

BRASIL. Lei $n^{\circ} 6.545$, de 30 de junho de 1978. Dispõe sobre a transformação das Escolas Técnicas Federais de Minas Gerais, do Paraná e Celso Suckow da Fonseca em Centros Federais de Educação Tecnológica, e dá outras providências. Brasília, 1978.

BRASIL. Lei $n^{\circ}$ 8.948, de 08 de dezembro de 1994. Dispõe sobre a instituição do Sistema Nacional de Educação Tecnológica, e dá outras providências. Brasília, 1994.

BRASIL. Lei $n^{0}$ 9. 394, de 20 de dezembro de 1996. Diretrizes e Bases da Educação Nacional. Brasília, 1996.

BRASIL/MEC. Planejamento Político-Estratégico 1995/1998. Brasília, 1995.

BRASIL/MEC. Plano de implementação da reforma da educação profissional, quadriênio 1999-2002. Brasília. 1999.

BRASIL/ MEC. Referenciais Curriculares Nacionais. Brasília, 2000.

BRASIL/MEC/CNE/CEB. Parecer $n^{\circ}$ 17, de 3 de dezembro de 1997. Dispõe sobre as Diretrizes Operacionais para a Educação Profissional em nível nacional. 
BRASIL/ MEC/CNE/CEB. Parecer $n^{\circ}$ 15/98, de 1 de junho de 1998. Dispõe sobre as Diretrizes Curriculares para o Ensino Médio.

BRASIL/MEC/CNE/CEB. Parecer $n^{0}$ 16, de 5 de outubro de 1999. Dispõe sobre as Diretrizes Curriculares Nacionais para Educação Profissional de Nível Técnico.

BRASIL/ MEC/CNE/CEB. Resolução $n^{\circ}$ 3, de 26 de junho de 1998. Institui as Diretrizes Curriculares Nacionais para o Ensino Médio.

BRASIL/MEC/CNE/CEB. Resolução $n^{\circ} 4$, de 4 de outubro de 1999. Institui as Diretrizes Curriculares Nacionais para a Educação Profissional de Nível Técnico. BRASIL/MEC/SENET/CEFET-RJ. Anais do Seminário Internacional de Educação Tecnológica. Rio de Janeiro, 1991.

BRASIL/MEC/SESU/SEMTEC. Os CEFETs no eixo das Instituições Federais de Ensino Superior . Brasília: CONCEFET - MEC/SESu/SEMTEC, 1997.

CAMPELLO, Ana Margarida de M. Barreto. A "cefetização" das escolas técnicas federais. Niterói, 2005. 188f. Tese (Doutorado em Educação). Centro de Estudos Sociais Aplicados, Faculdade de Educação, Universidade Federal Fluminense, Niterói, 2005.

CARVALHO, José Murilo de. Cidadania no Brasil: o longo caminho. 6. ed. Rio de Janeiro: Civilização Brasileira, 2004.

CENTRO PESQUISA E DOCUMENTAÇÃO DE HISTÓRIA CONTEMPORÂNEA DO BRASIL (CPDOC). Disponível em http://www.cpdoc.fgv.br/comum/htm/.

CIAVATTA, Maria. A formação integrada: a escola e o trabalho como lugares de memória. In: FRIGOTTO, Gaudêncio; CIAVATTA, Maria e RAMOS; Marise. Ensino médio integrado: concepções contradições. São Paulo: Cortez, 2005.

CUNHA, Luiz Antônio. O ensino profissional na irradiação do industrialismo. São Paulo: UNESP, Brasília, DF: Flacso, 2000.

Educação Profissional na América Latina: Brasil, Argentina e Chile. In: FAUSTO, Airton; PRONKO, Marcela; YANNOULAS, Silvia (Orgs). Políticas públicas de trabalho e Renda na América Latina e Caribe. Tomo I e Tomo II. Brasília: FLACSO/Brasil, 2003. Disponível em: http://www.flacso.org.br/data/biblioteca/351.pdf.

FERNANDES, Florestan. Em busca do socialismo: últimos escritos \& outros textos. São Paulo: Xamã, 1995.

FRIGOTTO, Gaudêncio. A produtividade da escola improdutiva: um (re) exame das relações entre educação e estrutura econômico-social e capitalista. 7 . ed. São Paulo: Cortez, 2001.

Anos 1980 e 1990: a relação entre o estrutural e o conjuntural e as políticas de educação tecnológica e profissional. In: FRIGOTTO, Gaudêncio; CIAVATTA, 
Maria. A formação do cidadão produtivo: a cultura de mercado no ensino médio técnico. Brasília: INEP, 2006.

; RODRIGUES, José. Ítalo Bologna. In: FÁVERO e BRITTO (Orgs.). Dicionário de educadores no Brasil. Rio de Janeiro: UFRJ/MEC-Inep-Comped, 2002.

FRIGOTTO, Gaudêncio, CIAVATTA, Maria. Educação básica no Brasil na década de 1990: subordinação ativa e consentida à lógica do mercado. IN: Educação \& Sociedade: Revista da Ciência da Educação. Campinas, v. 24, n. 82, p. 93-130, abr./2003.

. Educar o trabalhador cidadão produtivo ou o ser humano emancipado?. In: FRIGOTTO, Gaudêncio, CIAVATTA, Maria (Orgs.). A formação do cidadão produtivo: a cultura de mercado no ensino médio e técnico. Brasília: INEP, 2006.

; CIAVATTA, Maria; MAGALHÃES, Ana Lúcia. Programa de melhoria e expansão do ensino técnico: expressão de um conflito de concepções de educação tecnológica. In: FRIGOTTO, Gaudêncio, CIAVATTA, Maria (Orgs.). A formação do cidadão produtivo: a cultura de mercado no ensino médio e técnico. Brasília: INEP, 2006.

FONSECA, Celso Suckow da. História do ensino industrial no Brasil. RJ: Composto e Impresso no Curso de Tipografia e Encadernação da Escola Técnica Nacional, 1961.

GRAMSCI, Antonio. Cadernos do Cárcere, v. 4. Temas de cultura; Ação católica; Americanismo e fordismo. 2.ed. Rio de Janeiro: Civilização Brasileira, 2001.

IANNI, Octavio. Imperialismo na América Latina. 2. ed. Rio de Janeiro: Civilização Brasileira, 1988.

INSTITUTO DE PESQUISA ECONÔMICA APLICADA. Modernização tecnológica e formação técnico-profissional no Brasil: impasses e desafios. Texto para discussão no 295. Brasília: IPEA, Mar/1993.

MARINI, Ruy Mauro. Dialética da dependência. Petrópolis, RJ: Vozes; Buenos Aires: CLASO, 2000.

LEHER, Roberto. Da ideologia do desenvolvimento à ideologia da globalização: a educação como estratégia do Banco Mundial para "alívio" da pobreza. São Paulo, 1998. 267f. Tese (Doutorado em Educação). Faculdade de Educação da Universidade de São Paulo, São Paulo, 1998.

NASCIMENTO, Oswaldo Vieira do. O ensino industrial no Brasil:75 anos do ensino técnico ao ensino superior. Rio de Janeiro, 1986. 60f. Monografia (Série Monografias SENAI-DN). SENAI/DN/DPEA, Rio de Janeiro, 1986.

RAMOS, Marise. Do ensino técnico à educação tecnológica: (a)-historicidade das políticas dos anos 90. Niterói, 1995. Dissertação (Mestrado em Educação) Faculdade de Educação, Universidade Federal Fluminense, Niterói, 1995. 
- O projeto unitário de ensino médio sob os princípios do trabalho, da ciência e da cultura. In: FRIGOTTO Gaudêncio; CIAVATTA Maria (Orgs.). Ensino médio: ciência, cultura e trabalho. Brasília: MEC, SEMTEC, 2004.

RODRIGUES, José. O Moderno príncipe: o pensamento pedagógico empresarial da Confederação Nacional da Indústria. Campina, SP: Autores Associados, 1998.

. Celso Suckow da Fonseca e a sua "História do ensino industrial no Brasil". Revista Brasileira de História da Educação. Campinas: Autores Associados, jul./dez. 2002, n. 4. Disponível em: http://www.sbhe.org.br/novo/rbhe/RBHE4.pdf.

SANTOS, Jailson Alves dos. As bases da reforma do ensino médio e da educação profissional de nível técnico: as tramas das forças políticas no Congresso Nacional na tramitação da $L D B$. Tese (Doutorado em Educação) - Universidade Federal Fluminense, Niterói, Rio de Janeiro, 2006. Disponível em:

http://www.uff.br/pos educacao/joomla/index.php?option=com content\&task=view\&i $\mathrm{d}=68 \&$ Itemid $=32$.

SAVIANI, Dermeval. A nova lei da educação: trajetória, limites e perspectivas. 8. ed. Campinas, SP: Autores Associados, 2003.

SETUBAL, Olavo. Política industrial na década de 1990. In: BRASIL/MDIC/STI. Cronologia do desenvolvimento científico, tecnológico e industrial brasileiro 19382003. Brasília: MDIC/STI: SEBRAE: IEL/CNI, 2005.

SILVEIRA, Zuleide Simas da. Tecnologia e sociedade: a questão da nãocentralidade do trabalho. Revista tecnologia \& Cultura. Rio de Janeiro: Centro Federal de Educação Tecnológica Celso Suckow da Fonseca. Ano 7, n 7, jul./dez. 2005

. Contradições entre capital e trabalho: concepções de educação tecnológica na reforma do ensino médio e técnico. Dissertação (Mestrado em Educação) Universidade Federal Fluminense, Niterói, Rio de Janeiro, 2007. Disponível em: http://www.uff.br/pos educacao/joomla/images/stories/Teses/zuleidesilveira07.pdf.

UNESCO. Recomendação a todos os países da ONU. In: BRASIL/MEC. Revista Ensino Industrial, n.1, ano 1. Brasília: MEC/CBAI/DEI, 1962.

UNESCO. Declaração Mundial Sobre Educação Para Todos - Satisfação das Necessidades Básicas em Aprendizagem. Disponível em : www.unesco.org.br/publicações

UNESCO. Recomendacion para la Ejecucion Del Proyecto Principal de Educación en el Período 1993-1996. Disponível em : www.unesco.org.br/publicações 